Article

\title{
Transcriptome Changes Induced by Different Potassium Levels in Banana Roots
}

\author{
Yingdui $\mathrm{He}^{1,2,4}$, Ruimei $\mathrm{Li}^{3}$, Fei Lin ${ }^{2}$, Ying Xiong ${ }^{2,3,4}$, Lixia Wang ${ }^{2}$, Bizun Wang ${ }^{2}$, \\ Jianchun Guo ${ }^{1,3,4, *}$ and Chengxiao $\mathrm{Hu}^{1, *}$ \\ 1 College of Resource and Environment, Huazhong Agricultural University, Wuhan 430070, China; \\ heyd@catas.cn \\ 2 Haikou Experimental Station, Chinese Academy of Tropical Agricultural Sciences, Haikou 571101, China; \\ linfei198201@catas.cn (F.L.); xiongying950125@163.com (Y.X.); wlxmm@catas.cn (L.W.); \\ Wangbizun168@catas.cn (B.W.) \\ 3 Institute of Tropical Bioscience and Biotechnology, Chinese Academy of Tropical Agricultural Sciences, \\ Haikou 571101, China; liruimei@itbb.org.cn \\ 4 College of Tropical Crops, Hainan University, Haikou 570228, China \\ * Correspondence: guojianchun@itbb.org.cn (J.G.); hucx@mail.hzau.edu.cn (C.H.); Tel.: +86-898-6696-2953 \\ (J.G.); +86-027-8728-2026 (C.H.)
}

Received: 22 November 2019; Accepted: 16 December 2019; Published: 19 December 2019

\begin{abstract}
Potassium plays an important role in enhancing plant resistance to biological and abiotic stresses and improving fruit quality. To study the effect of potassium nutrient levels on banana root growth and its regulation mechanism, four potassium concentrations were designed to treat banana roots from no potassium to high potassium. The results indicated that $\mathrm{K} 2\left(3 \mathrm{mmol} / \mathrm{L} \mathrm{K}_{2} \mathrm{SO}_{4}\right)$ treatment was a relatively normal potassium concentration for the growth of banana root, and too high or too low potassium concentration was not conducive to the growth of banana root. By comparing the transcriptome data in each treatment in pairs, 4454 differentially expressed genes were obtained. There were obvious differences in gene function enrichment in root systems treated with different concentrations of potassium. Six significant expression profiles (profile $0,1,2,7,9$ and 13) were identified by STEM analysis. The hub genes were FKF1, HsP70-1, NRT1/PTR5, CRY1, and ZIP11 in the profile 0; CYP51 in profile 1; SOS1 in profile 7; THA, LKR/SDH, MCC, C4H, CHI, F3' H, 2 PR1s, $B S P, T L P, I C S, R O$, chitinase and peroxidase in profile 9 . Our results provide a comprehensive and systematic analysis of the gene regulation network in banana roots under different potassium stress.
\end{abstract}

Keywords: potassium; banana; transcriptome; root

\section{Introduction}

Potassium is a highly mobile nutrient mass that is an integral part of many physiological and biochemical processes in plants [1]. Potassium is essential for many cell and tissue activities, such as osmoregulation, enzyme activity, transport of minerals and metabolites, and stomatal aperture regulation [2-7]. It is involved in programmed cell death and senescence [8,9]. It also plays important roles in increasing plant resistance to disease [10-13]. Potassium deficiency can reduce plant photosynthesis, transpiration rate and stomatal conductance, and affect crop growth, yield quality and resistance to biological and abiotic stresses [7,14]. When plants face nutrient starvation in the soil, they will adjust the structure of root system and use the remaining resources to find a more favorable soil environment [15]. Arabidopsis thaliana significantly reduced lateral root elongation under low potassium treatment $[16,17]$. Maize varieties with high potassium uptake rate had advantages over those with low potassium uptake rate in terms of root length, root volume and root surface 
area [18]. The lack of potassium had a significant effect on the growth of rapeseed, and the lack of potassium significantly inhibited the growth of taproots and lateral roots [19]. Potassium deficiency of tobacco decreased root growth and mainly affected the formation and elongation of primary lateral roots [20]. Low potassium not only significantly reduced the dry weight of cabbage root, but also reduced its leaf area [21]. Therefore, the morphological structure of root system was greatly affected by potassium stress. It is significant to study the response mechanism of root system under potassium stress. There has been extensive research on root structural changes in response to stress of nutrients such as phosphate and nitrate and the signaling pathways that mediate these changes [22], and practical breakthroughs have been made. However, the mechanism of root structural change and response to potassium stress is still unclear.

With the purpose to explore the molecular mechanism of plant root response to potassium pressure, there are more and more reports on transcriptome, metabolome and proteomics of potassium stress (especially low potassium stress) in recent years. Transcriptome responses to K starvation in Arabidopsis thaliana [16], rice [4], soybean [23] and wild barley [24] indicated that genes related to ion transport, metabolism, signal transduction and protein phosphorylation significantly changed. Transcriptional analysis of sugarcane under low potassium stress showed significant differences in the expression of transcription factors, ion transporters, protein kinases and genes related to oxidative stress in the $\mathrm{Ca}^{2+}$ signal and ethylene signal pathways [25]. The results of transcriptome of rice potassium deficient seedlings showed that gene expression involved in nutrient transport, protein kinase, transcription process and plant hormone was significantly changed in roots [26]. Metabolomics analysis of tomato showed that potassium deficiency led to the soluble amino acids and soluble sugars increase in roots, meanwhile the organic acids and amino acids decrease in leaves [27]. ITRAQ proteome assessment showed that the differentially expressed proteins in wheat under low potassium stress showed organ-specific differences. In addition, most of the differently expressed proteins associated with hormone synthesis were found to be involved in JA synthesis [28].

Banana (Musa acuminata L.) is a kind of large herbaceous tropical and subtropical fruit tree. It is considered to be a potassium-loving fruit tree. In production, a large amount of potash fertilizer is often applied to increase banana yield, improve fruit quality and storage, and enhance plant resilience. However, due to the constant erosion of soil by seasonal rain, potassium was largely lost through leaching, and the use rate of potash fertilizer was less than 30\% [29]. Excessive application of fertilizer not only causes waste, but also causes environmental pollution. Therefore, to explore the mechanism and regulation of banana response to low potassium stress is a feasible way to improve the use efficiency of banana potassium fertilizer and improve the efficiency of banana industry. In this study, "Brazilian" banana, the major variety planted in China, was used as an experimental subject. RNA-seq technology was applied on the roots to reveal the molecular mechanism of root growth affected by different potassium concentrations. Some important hub genes associated with ion transport, cell wall modification, transcript factors, hormone signaling were identified. This study provides an idea for the analysis of the molecular mechanism of potassium ion regulating banana root growth.

\section{Results}

\subsection{Morphology Changes of Banana Roots after Potassium Treatments}

Banana roots exposure to different concentration of potassium showed a significant different growth phenotype. The roots that treated with $\mathrm{K} 2\left(3 \mathrm{mmol} / \mathrm{L} \mathrm{K}_{2} \mathrm{SO}_{4}\right)$ concentration grew best, with strongest root and most root hairs (Figure 1). From $\mathrm{K} 0\left(0 \mathrm{mmol} / \mathrm{L} \mathrm{K}_{2} \mathrm{SO}_{4}\right)$ to $\mathrm{K} 2$, the total length of the roots does not change much, but the number of roots and root hairs increased with the potassium concentration. However, feed with the high level of potassium $\left(\mathrm{K} 3,200 \mathrm{mmol} / \mathrm{L} \mathrm{K}_{2} \mathrm{SO}_{4}\right)$, the roots got the longest root length, but less root numbers and root hairs (Figure 1). These results indicated that both too low or too high potassium concentrations inhibit the growth of banana roots, but in different ways. 


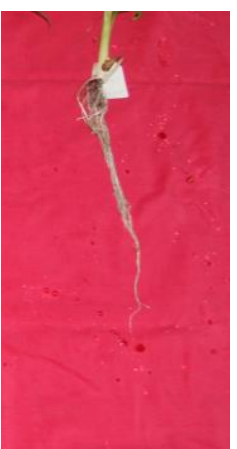

K0

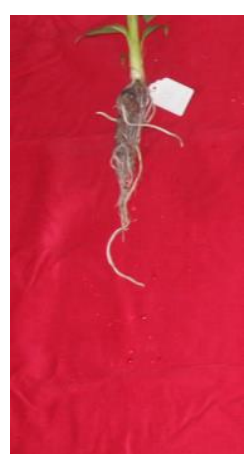

K1

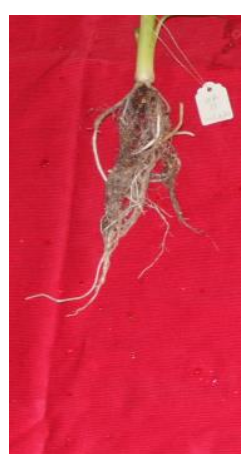

K2

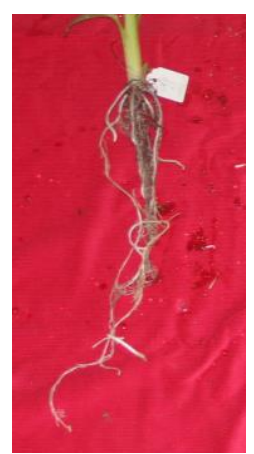

K3

Figure 1. Effects of different concentration of potassium stress on the growth of banana roots. K0: 0 $\mathrm{mmol} / \mathrm{L} \mathrm{K}_{2} \mathrm{SO}_{4}$ treated banana root; K1: $0.03 \mathrm{mmol} / \mathrm{L} \mathrm{K}_{2} \mathrm{SO}_{4}$ treated banana root; $\mathrm{K} 2: 3 \mathrm{mmol} / \mathrm{L} \mathrm{K}_{2} \mathrm{SO}_{4}$ treated banana root; K3: $200 \mathrm{mmol} / \mathrm{L} \mathrm{K}_{2} \mathrm{SO}_{4}$ treated banana root.

\subsection{Overview of Transcriptome Sequencing Results}

To overview the banana roots gene expression patterns at different potassium supply conditions, we carried out the RNA-seq analysis. Seedling root samples treated as K0, K1, K2 and K3, were sequenced. Approximately 24.02 to 34.47 million 150 bp paired-end clean reads were obtained from $\mathrm{K} 0, \mathrm{~K} 1, \mathrm{~K} 2$ and K3 samples, respectively. The average Q20 contents were $94.01 \%$ to $94.15 \%$, and GC contents were $53.58 \%$ to $54.26 \%$, respectively. These data indicate that the sequencing results were fine. The mapped reads information among K0, K1, K2 and K3 samples was: $77.27 \%$ to $83.37 \%$ of the total mapping ratio (Table 1). The transcriptome data was qualified and considered appropriate for subsequent analysis.

Table 1. Summary of RNA-seq data and reads mapping.

\begin{tabular}{cccccccc}
\hline & Raw Data & $\begin{array}{c}\text { Clean } \\
\text { Data }\end{array}$ & Q20 (\%) & GC (\%) & $\begin{array}{c}\text { Unique } \\
\text { Mapped }\end{array}$ & $\begin{array}{c}\text { Multiple } \\
\text { Mapped }\end{array}$ & $\begin{array}{c}\text { Mapping } \\
\text { Ratio (\%) }\end{array}$ \\
\hline K0 & $28,043,505$ & $27,574,822$ & 94.01 & 53.96 & $21,674,956$ & 92,502 & 79.23 \\
K1 & $30,165,251$ & $29,675,721$ & 94.13 & 53.58 & $22,955,324$ & 74,451 & 77.27 \\
K2 & $35,061,437$ & $34,465,589$ & 94.02 & 53.95 & $27,718,870$ & 94,409 & 79.81 \\
K3 & $24,438,772$ & $24,024,081$ & 94.15 & 54.26 & $20,030,295$ & 50,940 & 83.37 \\
\hline
\end{tabular}

\subsection{Different Concentration of Potassium Stresses Affect Genes Expression in Banana Roots}

More than $68 \%$ of the genes had gene expression levels of FPKM $\geq 2$ in each evaluated instance. Among the above gene clusters, more than $70 \%$ of genes were FPKM $<25$, and more than $25 \%$ had FPKM between 10 and 25 (Table S1). About 3\% of genes had FPKM values more than 200. It is clear that the gene expression levels in the four treatments displayed the same trend (Figure 2A). The gene expression distribution analysis showed that among the 24,277 genes with FPKM $\geq 2,19,872(82 \%)$ genes were expressed in all four potassium treatments, while a small number were expressed only in one condition ( $2.8 \%$ of $\mathrm{K} 0,1.5 \%$ of $\mathrm{K} 1,0.8 \%$ of $\mathrm{K} 2$, and $1.3 \%$ of $\mathrm{K} 3$ ) (Figure $2 \mathrm{~B}$ ).

By comparing each treatment in pairs, 4454 differently expressed genes (DEGs) were obtained (Figure 3). Compared to K0, 1032 (645 up-regulated, 387 down-regulated), 1445 (395 up-regulated, 1050 down-regulated), and 1695 (366 up-regulated, 1329 down-regulated) DEGs were detected after K1, K2 and K3 treatments, respectively (Figure 3). Compared to K1, a total of 935 (175 up-regulated, 760 down-regulated), and 1553 (195 up-regulated, 1358 down-regulated) DEGs were detected after K2 and K3 treatments, respectively (Figure 3). Compared to K2, 1050 (482 up-regulated, 668 down-regulated) DEGs were found after K3 treatment (Figure 3). 
A

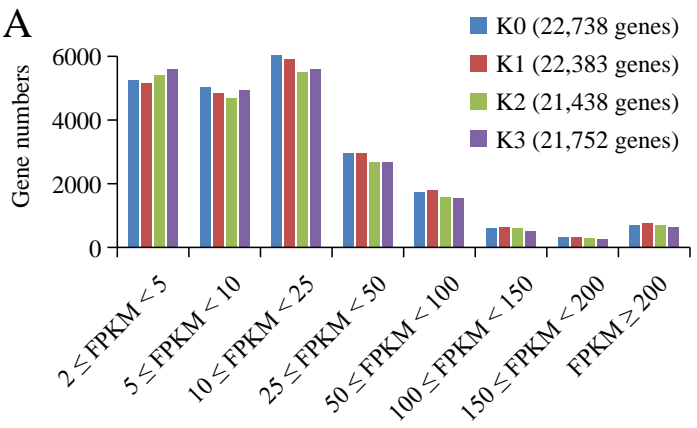

B

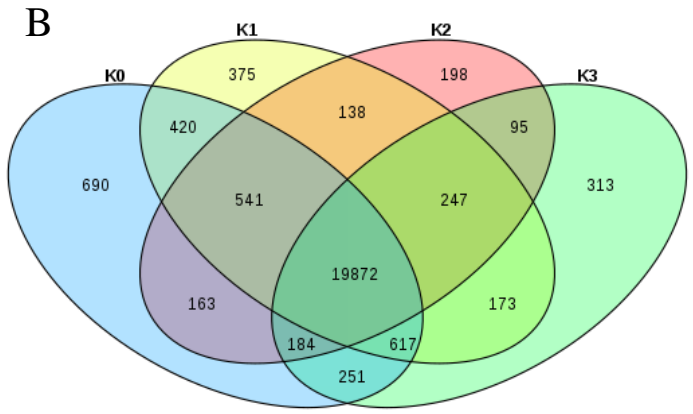

Figure 2. Transcript abundance measurements at each potassium concentration treatment. (A) The frequency represents the number of genes per category according to FPKM expression value. The number of total considered expressed genes (FPKM $\geq 2$ ) for each moment is presented in brackets. (B) Venn diagram of expressed genes (FPKM $\geq 2$ ) for each library (K0: 22,738 genes; K1: 22,383 genes; K2: 21,438 genes; K3: 21,752 genes). The number of common expressed genes in each intersection area is presented.

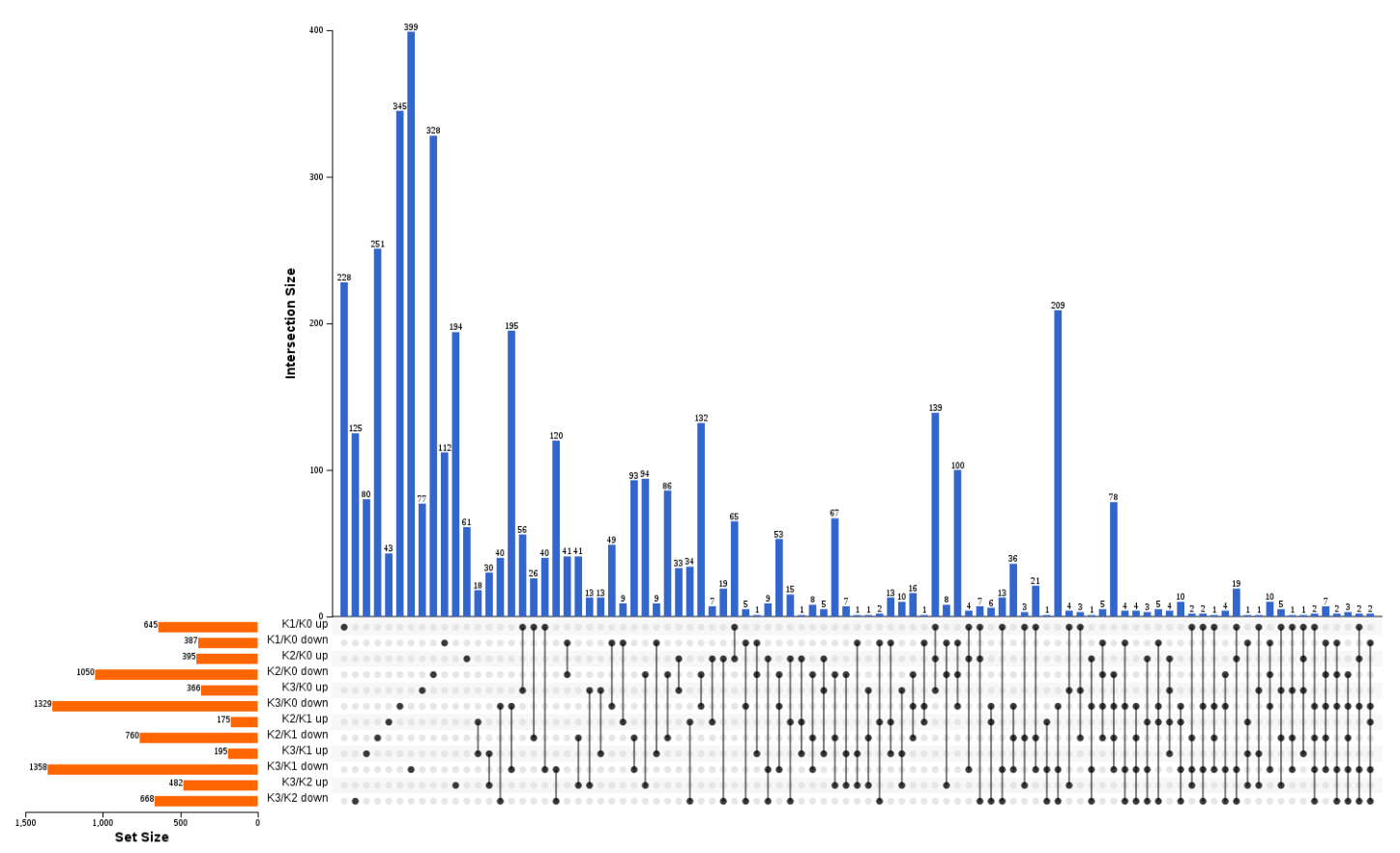

Figure 3. Upset Venn illustrating the number of DEGs between different concentration potassium treated banana roots. The horizontal orange bar graph on the left side represents the element statistics of each set, the single black point in the middle matrix represents the element unique to a set, the line between points and points represents the intersection unique to different sets, and the vertical blue bar graph represents the corresponding intersection element values.

\subsection{Gene function Enrichment Analysis of DEGs in Responses to $\mathrm{K}^{+}$Treatments}

Gene ontology (GO) analysis was conducted to elucidate the molecular function of the DEGs detected in banana roots from $\mathrm{K} 1, \mathrm{~K} 2$ and $\mathrm{K} 3$ compared to $\mathrm{K} 0$ using the OMICSHARE online program (Table S2). Many GO terms were significantly enriched (adjusted $p<0.05$ ) and the GO terms enriched in three kind potassium treatments were different (Table S2). 21 GO terms were enriched in K1 up-regulated DEGs, while 7 GO terms were significantly enriched in K1 down-regulated DEGs. 9 GO terms in K2 up-regulated DEGs, while 13 GO terms were enriched in K2 down-regulated DEGs. 5 GO terms were enriched in K3 up-regulated DEGs, while 19 GO terms were enriched in K3 down-regulated DEGs. In K1 up-regulated DEGs, the "glycopeptide alpha-N-acetylgalactosaminidase activity", "manganese 
ion binding", "nutrient reservoir activity", "transporter activity" related, "ATPase activity" related, "hydrolase activity, acting on acid anhydrides, catalyzing transmembrane movement of substances" related, and "transferase activity, transferring acyl groups" GO terms were specific enriched. In K1 down-regulated DEGs, the "cysteamine dioxygenase activity", "xyloglucan:xyloglucosyl transferase activity", "dioxygenase activity", and "hydrolase activity, acting on glycosyl bonds" GO terms were specific enriched In K2 up-regulated DEGs, the "linoleate 13S-lipoxygenase activity" GO term was specific enriched. In K2 down regulated DEGs, the "sequence-specific DNA binding" GO term was specific enriched. In K3 down-regulated DEGs, the "methylcrotonoyl-CoA carboxylase activity", "chitin binding", "peroxidase activity", "oxidoreductase activity, acting on peroxide as acceptor", and "antioxidant activity" GO terms were specific enriched. While in K3 up-regulated DEGs, no GO term was specific enriched (Figure 4, Table S2). These result suggested that banana roots require genes with different functions to survive with different potassium concentrations.

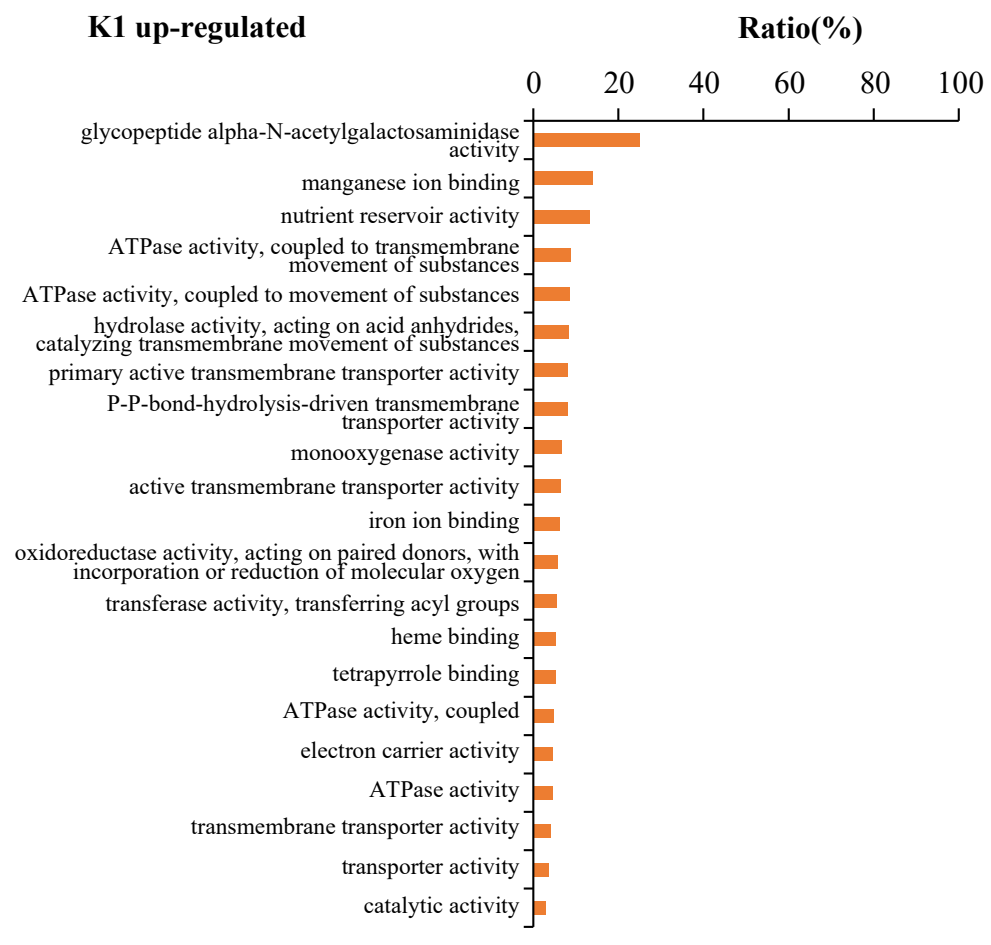

K1 down-regulated

Ratio (\%)

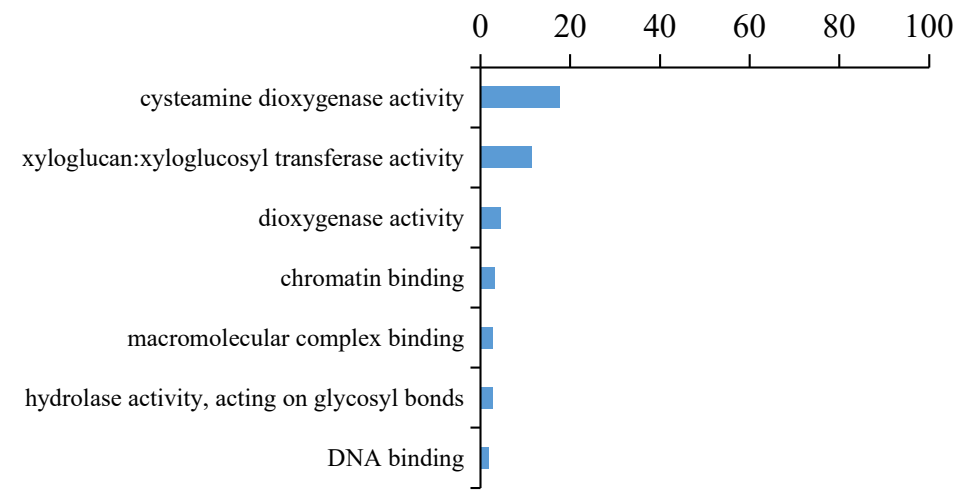

Figure 4. Cont. 


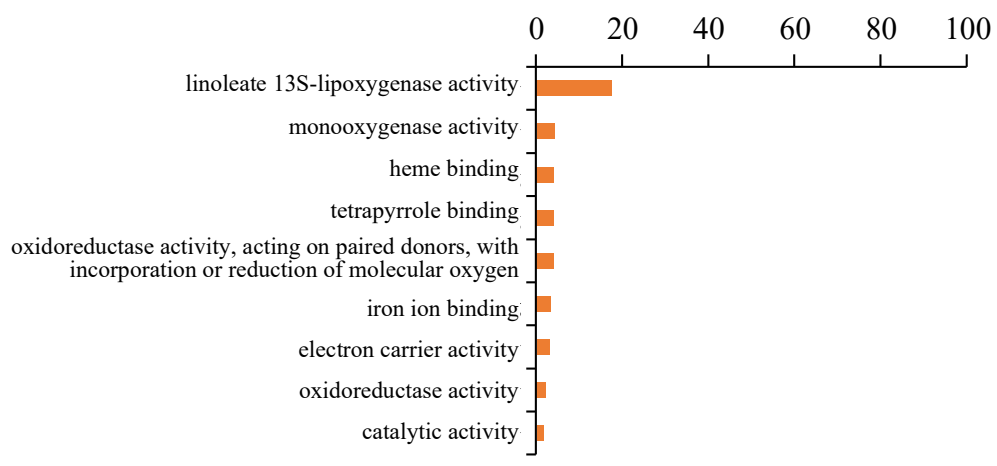

\section{K2 down-regulated}

Ratio (\%)

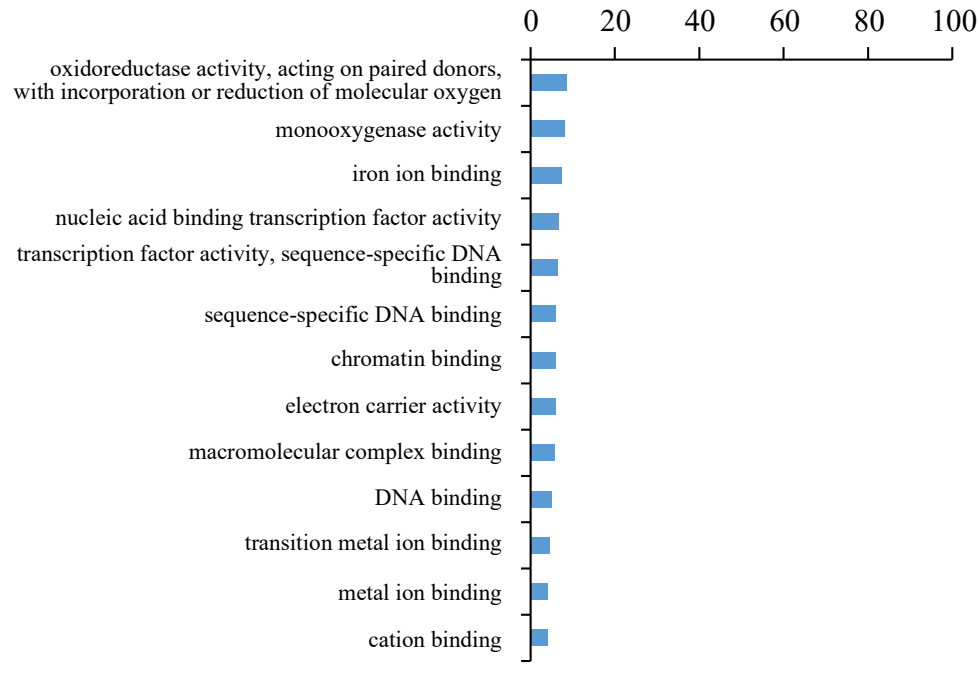

\section{K3 up-regulated}

Ratio (\%)

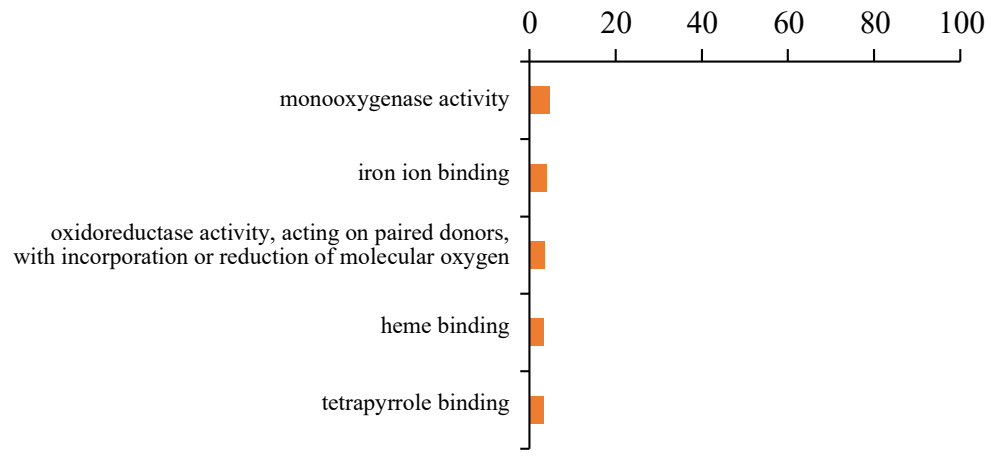

Figure 4. Cont. 
K3 down-regulated

Ratio (\%)

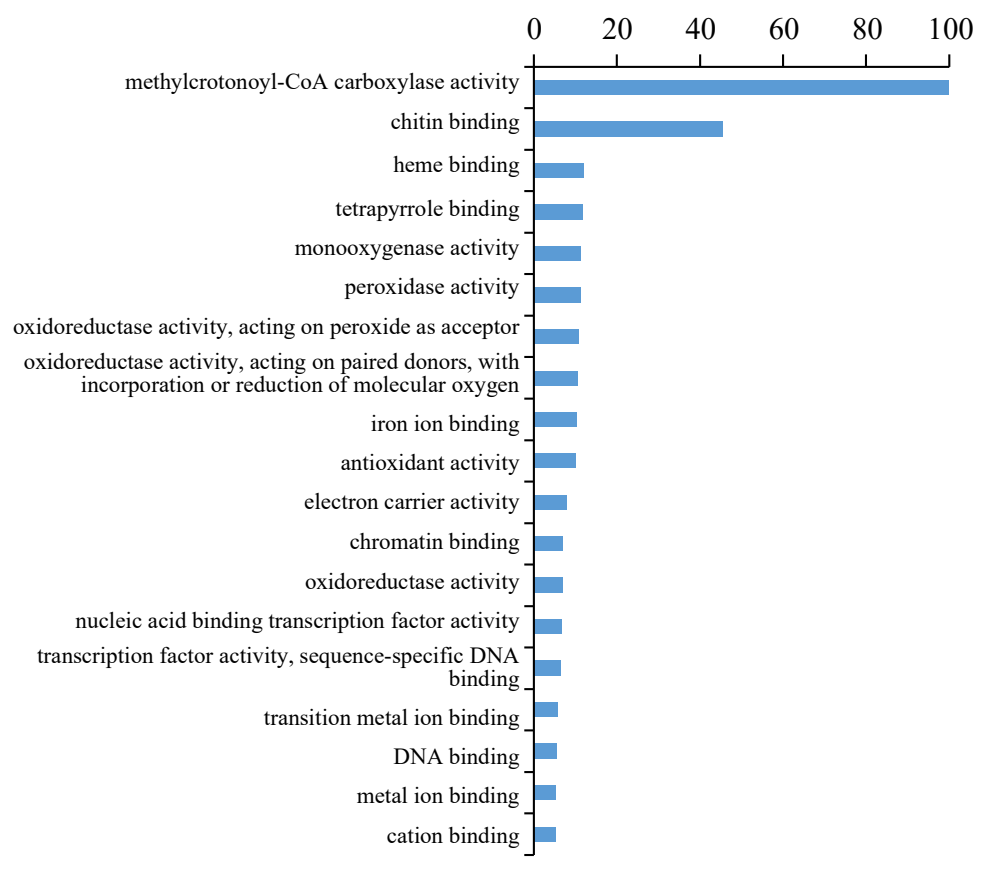

Figure 4. GO molecular function analysis of DEGs detected in banana roots in response to different concentration of potassium. The ratio was the proportion of the number of DEGs in the total number of genes in each GO term. K1 up-regulated: The GO terms significantly enriched in K1 up-regulated DEGs. K1 down-regulated: The GO terms significantly enriched in K1 down-regulated DEGs. K2 up-regulated: The GO terms significantly enriched in K2 up-regulated DEGs. K2 down-regulated: The GO terms significantly enriched in K2 down-regulated DEGs. K3 up-regulated: The GO terms significantly enriched in K3 up-regulated DEGs. K3 down-regulated: The GO terms significantly enriched in $\mathrm{K} 3$ down-regulated DEGs.

\subsection{Expression Trend Analysis}

The expression profiles of 4454 DEGs were determined and 20 candidate profiles were obtained (Figure 5A), in which six significant $(p<0.05)$ expression profiles (profile $0,1,2,7,9$ and 13) were identified. The 537 DEGs in Profile 0 were significantly present down-regulated with the potassium concentration increase. Profile 1 included 393 DEGs that were down-regulated from K0 to K2 and up-regulated from $\mathrm{K} 2$ to $\mathrm{K} 3$, which is consistent with the phenotype of the banana root growth. Profile 2 contained 241 DEGs down-regulated from K0 to K1 and present no change from K1 to K3. The 382 DEGs in Profile 7 presented no change from K0 and K1, K2 and K3, but down regulated from K1 to K2. In profile 9, the $596 \mathrm{DEGs}$ present no change in $\mathrm{K} 0$ to $\mathrm{K} 2$, but down-regulated from $\mathrm{K} 2$ to $\mathrm{K} 3$. In profile 13, 314 DEGs up-regulated from K0 to K1, then down-regulated to K3 (Figure 5). 

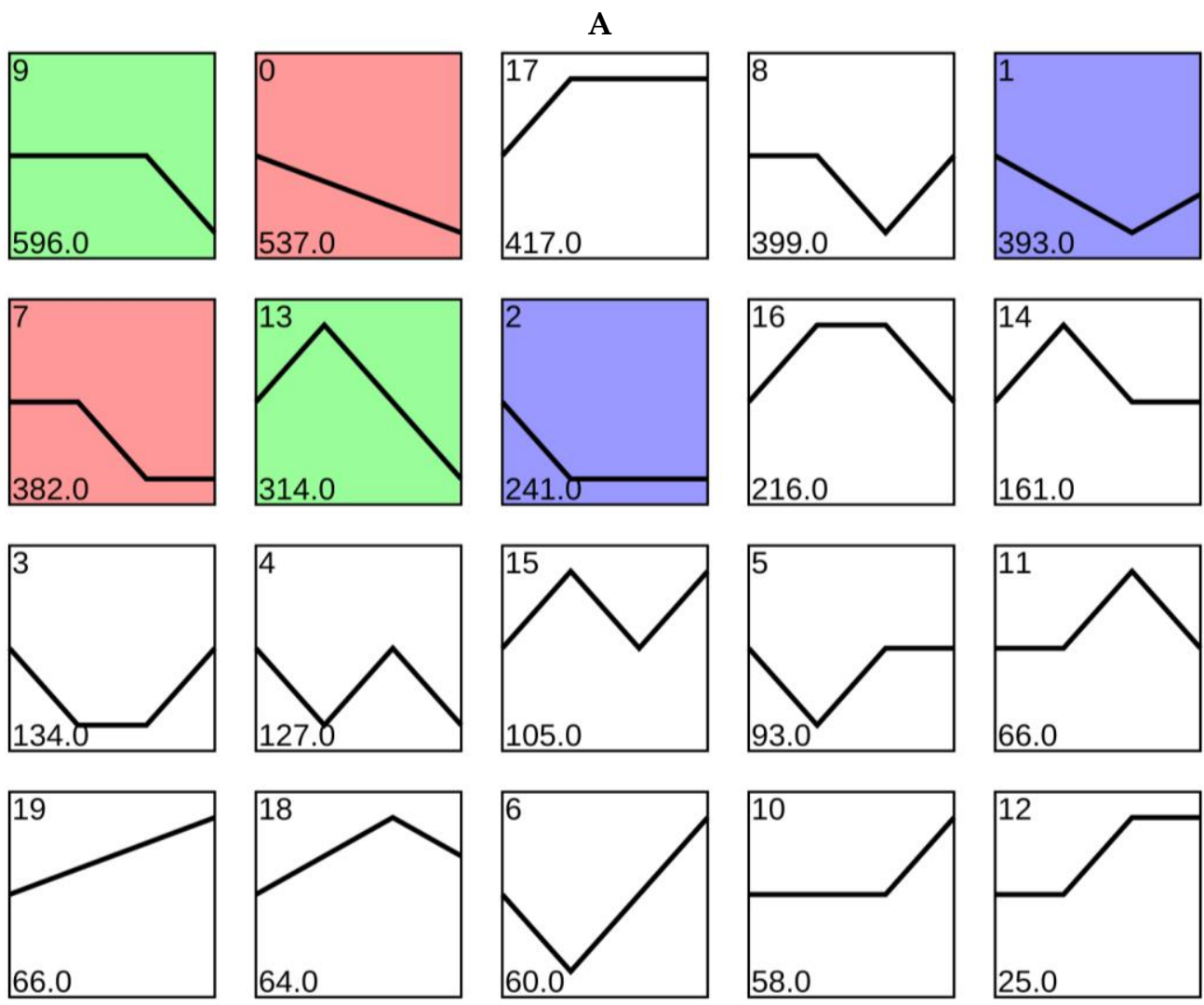

B
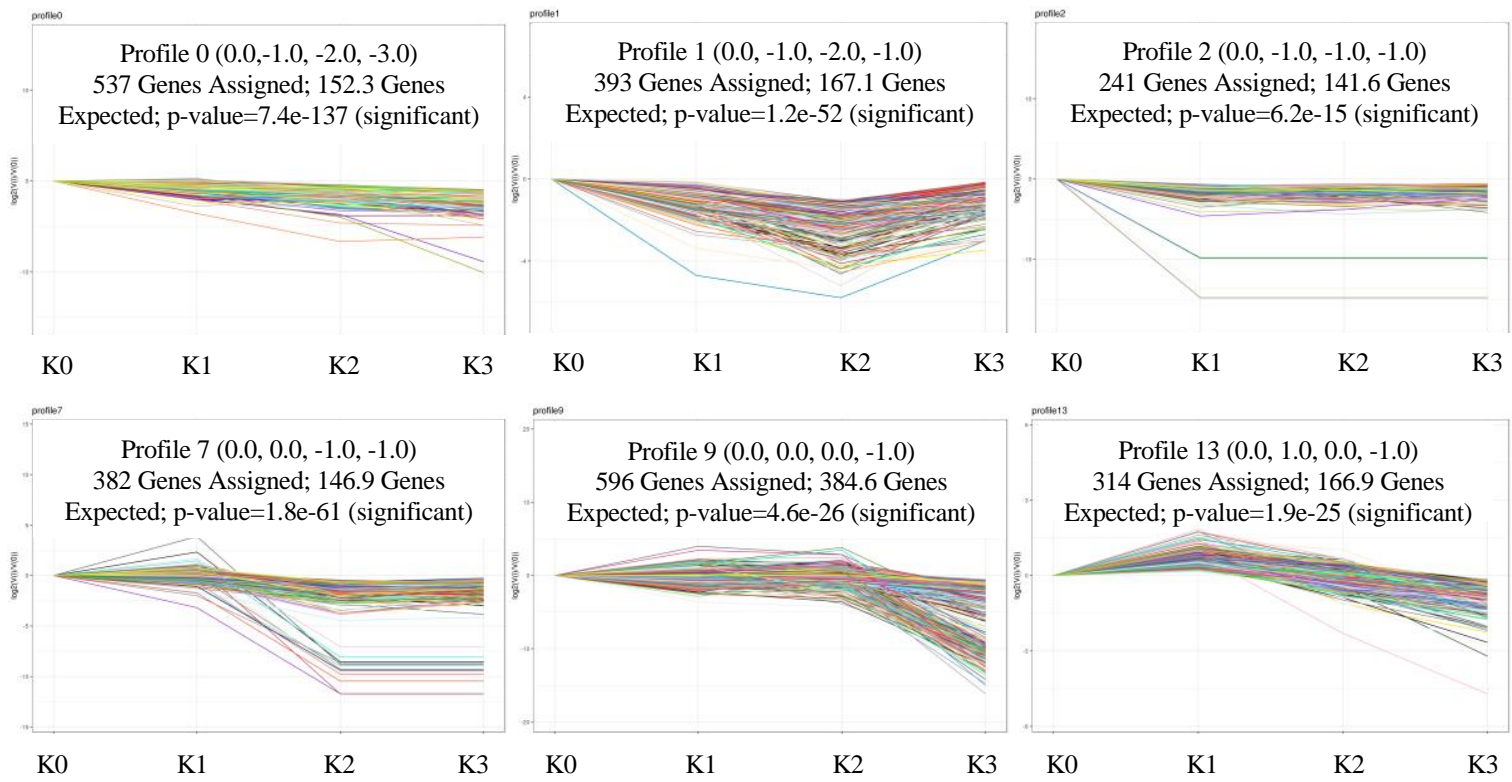

Figure 5. Short time-series expression miner (STEM) clustering on DEGs with the increase of potassium concentration. (A), all 20 profiles, with the colored profiles were significant $(p<0.05)$. (B), six significant gene expression profiles, with the number of genes and the $p$-value were shown. 


\subsection{GO Enrichment Analysis of the Six Significant Gene Expression Patterns}

To understand the functional enrichment of DEGs in the six significant profiles, we conducted GO analysis on them respectively, and regarded the adjusted $p$ value $<0.05$ as significant enrichment. There were 4, 1, 19, 21, and $2 \mathrm{GO}$ terms significantly enriched in profiles $0,1,7,9$ and 13 , and zero enriched in profile 2. Significant GO terms that were related to ion binding such as iron ion binding, transition metal ion binding, and manganese ion binding were enriched in profiles 7,9 , and 13. Significant GO terms such as transcription factor activity were enriched in profiles 0 and 7; oxidoreductase activity related GO terms were enriched in profiles 1,7, and 9 (Table 2). These results suggest that the banana root has evolved a range of molecular strategies that response in different potassium concentrations.

\subsection{Interaction Network Construction of the DEGs in Significant Expression Patterns}

To further reveal the interactive relationship among DEGs in the above six significant profiles, the DEGs in each pattern were uploaded to the STRING database to get the interaction network, respectively. In the profile 0 interaction network, five genes, including FKF1 (flavin-binding kelch repeat F-box protein 1, GSMUA_Achr7P11200_001), HsP70-1 (Heat shock cognate 70 kDa protein, GSMUA_Achr6P34210_001), NRT1/PTR5 (Peptide transporter PTR5, GSMUA_Achr5P22130_001), CRY1 (Cryptochrome-1, GSMUA_Achr6P02100_001), and ZIP11 (Zinc transporter 11, GSMUA_Achr8P26320_001), were strongly associated with other genes (connected notes more than 8 ), indicated that they were the core genes in profile 0 (Figure 6A). The five hub genes were connected by several transcription factors including MYBs and bHLHs. There were also many $H s P$ transcription factors in the network (Figure 6A, Tables S3 and S4). In the profile 1, CYP51 (Sterol 14-alpha-demethylase/Obtusufoliol 14-demethylase, Cytochrome P450 family, GSMUA_Achr10P12080_001), was the hub gene with the highest node degree 8 (Figure 6B, Tables S5 and S6). It direct interacted with one another CYP members, two DIMs (Cell elongation protein DIMINUTO), PNMT1 (Phosphoethanolamine N-methyltransferase 1), two sterol desaturase family members (C4MO, C-4 methylsterol oxidase; DSD, Delta(7)-sterol-C5(6)-desaturase), and one CPO (Coproporphyrinogen-III oxidase). In profile 7, SOS1 (Sodium/hydrogen exchanger 7, GSMUA_Achr8P16670_001) was the hub gene in the PPI network, exhibiting the highest (10) node degree (Figure 6C, Tables S7 and S8). Potassium transport-related genes such as KCO1, KT4, and KAT3, were direct or indirect connected with SOS1. Calcineurin B-like protein 4 (CBL), Disease resistance protein RPM1, CBL-interacting protein kinases (CIPK6 and CIPK23), and 3 Plasma membrane ATPase (PMA) family members were direct connected with SOS1. The SOS1 also indirect interacted with several CYP family members through CBL (Figure 6C). In profile 9, THA (Putative L-allo-threonine aldolase, GSMUA_Achr2P12200_001), LKR/SDH (Alpha-aminoadipic semialdehyde synthase, GSMUA_Achr10P23170_001), MCC (Methylcrotonoyl-CoA carboxylase beta chain, GSMUA_Achr1P21350_001), C4H (Trans-cinnamate 4-monooxygenase, GSMUA_Achr7P18320_001), CFI (Chalcone-flavonone isomerase, GSMUA_Achr4P16830_001), F3'H (Flavonoid 3'-monooxygenase, GSMUA_Achr3P30350_001), PR1s (Pathogenesis-related protein 1，GSMUA_Achr4P23100_001, GSMUA_Achr2P13240_001), BSP (Secretory protein, GSMUA_Achr11P22160_001), TLP (Thaumatin-like protein, GSMUA_Achr6P31470_001), ICS (Isochorismate synthase, GSMUA_Achr3P32520_001), RO (Reticuline oxidase, GSMUA_Achr3P23450_001), chitinase (GSMUA_Achr3P26900_001), and peroxidase (GSMUA_Achr9P23850_001), were the hub genes with the node degree more than 8 (Figure 6D, Tables S9 and S10). In profile 2 and profile 13, there were no gene with the node degree more than 8 (Figures S1 and S2). In profile 2, F-box/LRR-repeat protein 3 (GSMUA_Achr10P29380_001) was the hub gene with 4 nodes (Figure S1, Tables S11 and S12). In profile 13, MS (Malate synthasewas, GSMUA_Achr8P28810_001) was the hub gene and exhibited 7 nodes (Figure S2, Tables S13 and S14). 

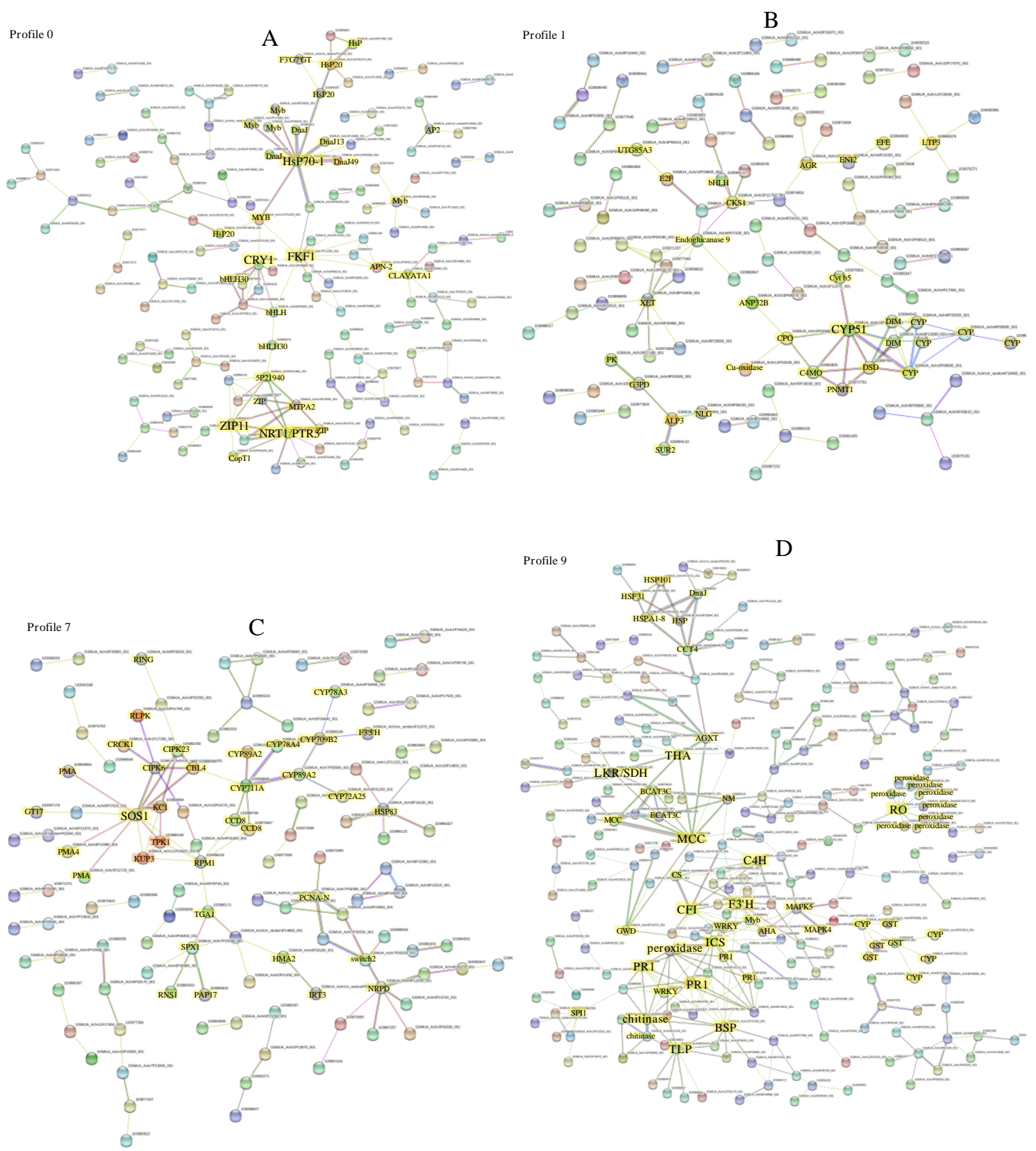

Figure 6. Interaction network of DEGs in profile 0,1,7 and 9. The hub genes were represented in the largest font. (A) Interaction network of DEGs in profile 0. (B) Interaction network of DEGs in profile 1. (C) Interaction network of DEGs in profile 7. (D) Interaction network of DEGs in profile 9.

\subsection{Validation of RNA Sequencing Data}

Quantitative real-time PCR (qRT-PCR) were performed to evaluate the accuracy of the gene expression in this transcriptome data. In this study, eight DEGs were randomly selected to detected by qRT-PCR. The expression patterns analysis showed that the qRT-PCR results were consistent with the transcriptome patterns. This result indicated that the RNA-Seq data was reliable (Figure 7). 
Table 2. Summary of GO molecular function analysis of six profiles.

\begin{tabular}{|c|c|c|c|c|c|c|}
\hline & GO Terms & Description & Out & All & p.Adjust & Ratio (\%) \\
\hline \multirow{4}{*}{ Profile 0} & GO:0003682 & chromatin binding & 23 & 585 & 0.007589488 & 3.93 \\
\hline & GO:0003700 & $\begin{array}{l}\text { transcription factor activity, } \\
\text { sequence-specific DNA binding }\end{array}$ & 35 & 1046 & 0.006265828 & 3.35 \\
\hline & GO:0001071 & $\begin{array}{c}\text { nucleic acid binding } \\
\text { transcription factor activity }\end{array}$ & 35 & 1057 & 0.006265828 & 3.31 \\
\hline & GO:0003677 & DNA binding & 77 & 2659 & 0.00010964 & 2.90 \\
\hline Profile 1 & GO:0016705 & $\begin{array}{l}\text { oxidoreductase activity, acting } \\
\text { on paired donors, with } \\
\text { incorporation or reduction of } \\
\text { molecular oxygen }\end{array}$ & 17 & 460 & 0.007235669 & 3.70 \\
\hline \multirow{19}{*}{ Profile 7} & GO:0008131 & primary amine oxidase activity & 3 & 10 & 0.01050813 & 30.00 \\
\hline & GO:0016641 & $\begin{array}{l}\text { oxidoreductase activity, acting } \\
\text { on the } \mathrm{CH}-\mathrm{NH} 2 \text { group of } \\
\text { donors, oxygen as acceptor }\end{array}$ & 3 & 14 & 0.013873365 & 21.43 \\
\hline & GO:0048038 & quinone binding & 4 & 25 & 0.01050813 & 16.00 \\
\hline & GO:0016638 & $\begin{array}{c}\text { oxidoreductase activity, acting } \\
\text { on the } \mathrm{CH}-\mathrm{NH} 2 \text { group } \\
\text { of donors }\end{array}$ & 3 & 24 & 0.04293938 & 12.50 \\
\hline & GO:0004713 & protein tyrosine kinase activity & 4 & 50 & 0.044647033 & 8.00 \\
\hline & GO:0004497 & monooxygenase activity & 11 & 255 & 0.012179367 & 4.31 \\
\hline & GO:0016705 & $\begin{array}{l}\text { oxidoreductase activity, acting } \\
\text { on paired donors, with } \\
\text { incorporation or reduction of } \\
\text { molecular oxygen }\end{array}$ & 16 & 460 & 0.01050813 & 3.48 \\
\hline & GO:0008324 & $\begin{array}{l}\text { cation transmembrane } \\
\text { transporter activity }\end{array}$ & 15 & 434 & 0.012179367 & 3.46 \\
\hline & GO:0009055 & electron carrier activity & 17 & 506 & 0.01050813 & 3.36 \\
\hline & GO:0005506 & iron ion binding & 13 & 420 & 0.040286999 & 3.10 \\
\hline & GO:0003700 & $\begin{array}{l}\text { transcription factor activity, } \\
\text { sequence-specific DNA binding }\end{array}$ & 32 & 1046 & 0.000516422 & 3.06 \\
\hline & GO:0001071 & $\begin{array}{c}\text { nucleic acid binding } \\
\text { transcription factor activity }\end{array}$ & 32 & 1057 & 0.000516422 & 3.03 \\
\hline & GO:0043565 & sequence-specific DNA binding & 19 & 644 & 0.013547559 & 2.95 \\
\hline & GO:0004674 & $\begin{array}{l}\text { protein serine/threonine } \\
\text { kinase activity }\end{array}$ & 26 & 1080 & 0.023435321 & 2.41 \\
\hline & GO:0004672 & protein kinase activity & 33 & 1498 & 0.023435321 & 2.20 \\
\hline & GO:0003677 & DNA binding & 53 & 2659 & 0.012179367 & 1.99 \\
\hline & GO:0046914 & transition metal ion binding & 39 & 1957 & 0.040286999 & 1.99 \\
\hline & GO:1901363 & heterocyclic compound binding & 123 & 7912 & 0.035080217 & 1.55 \\
\hline & GO:0097159 & $\begin{array}{l}\text { organic cyclic compound } \\
\text { binding }\end{array}$ & 123 & 7923 & 0.035080217 & 1.55 \\
\hline
\end{tabular}


Table 2. Cont.

\begin{tabular}{|c|c|c|c|c|c|c|}
\hline & GO Terms & Description & Out & All & p.Adjust & Ratio (\%) \\
\hline \multirow{21}{*}{ Profile 9} & GO:0004485 & $\begin{array}{l}\text { methylcrotonoyl-CoA } \\
\text { carboxylase activity }\end{array}$ & 2 & 2 & 0.010998085 & 100.00 \\
\hline & GO:0008061 & chitin binding & 6 & 11 & $1.37 \times 10^{-6}$ & 54.55 \\
\hline & GO:0004084 & $\begin{array}{l}\text { branched-chain-amino-acid } \\
\text { transaminase activity }\end{array}$ & 2 & 4 & 0.037470895 & 50.00 \\
\hline & GO:0052654 & L-leucine transaminase activity & 2 & 4 & 0.037470895 & 50.00 \\
\hline & GO:0052655 & L-valine transaminase activity & 2 & 4 & 0.037470895 & 50.00 \\
\hline & GO:0052656 & $\begin{array}{c}\text { L-isoleucine } \\
\text { transaminase activity }\end{array}$ & 2 & 4 & 0.037470895 & 50.00 \\
\hline & GO:0004568 & chitinase activity & 6 & 22 & $8.26 \times 10^{-5}$ & 27.27 \\
\hline & GO:0008762 & $\begin{array}{l}\text { UDP-N-acetylmuramate } \\
\text { dehydrogenase activity }\end{array}$ & 5 & 38 & 0.018018015 & 13.16 \\
\hline & GO:0004601 & peroxidase activity & 15 & 160 & $1.86 \times 10^{-5}$ & 9.38 \\
\hline & GO:0016684 & $\begin{array}{l}\text { oxidoreductase activity, acting } \\
\text { on peroxide as acceptor }\end{array}$ & 15 & 166 & $2.48 \times 10^{-5}$ & 9.04 \\
\hline & GO:0016209 & antioxidant activity & 16 & 191 & $2.48 \times 10^{-5}$ & 8.38 \\
\hline & GO:0020037 & heme binding & 30 & 446 & $1.74 \times 10^{-7}$ & 6.73 \\
\hline & GO:0046906 & tetrapyrrole binding & 30 & 455 & $1.86 \times 10^{-7}$ & 6.59 \\
\hline & GO:0050660 & $\begin{array}{l}\text { flavin adenine dinucleotide } \\
\text { binding }\end{array}$ & 9 & 157 & 0.043604233 & 5.73 \\
\hline & GO:0004497 & monooxygenase activity & 12 & 255 & 0.045573268 & 4.71 \\
\hline & GO:0016705 & $\begin{array}{l}\text { oxidoreductase activity, acting } \\
\text { on paired donors, with } \\
\text { incorporation or reduction of } \\
\text { molecular oxygen }\end{array}$ & 20 & 460 & 0.010998085 & 4.35 \\
\hline & GO:0004553 & $\begin{array}{l}\text { hydrolase activity, hydrolyzing } \\
\text { O-glycosyl compounds }\end{array}$ & 20 & 488 & 0.019555184 & 4.10 \\
\hline & GO:0005506 & iron ion binding & 17 & 420 & 0.037470895 & 4.05 \\
\hline & GO:0016491 & oxidoreductase activity & 69 & 1744 & $1.74 \times 10^{-7}$ & 3.96 \\
\hline & GO:0016798 & $\begin{array}{l}\text { hydrolase activity, acting on } \\
\text { glycosyl bonds }\end{array}$ & 20 & 516 & 0.035644596 & 3.88 \\
\hline & GO:0003824 & catalytic activity & 224 & 9724 & $3.52 \times 10^{-5}$ & 2.30 \\
\hline \multirow{2}{*}{ Profile 13} & GO:0030145 & manganese ion binding & 5 & 43 & 0.01549229 & 11.63 \\
\hline & GO:0045735 & nutrient reservoir activity & 5 & 45 & 0.01549229 & 11.11 \\
\hline
\end{tabular}


qRT-PCR
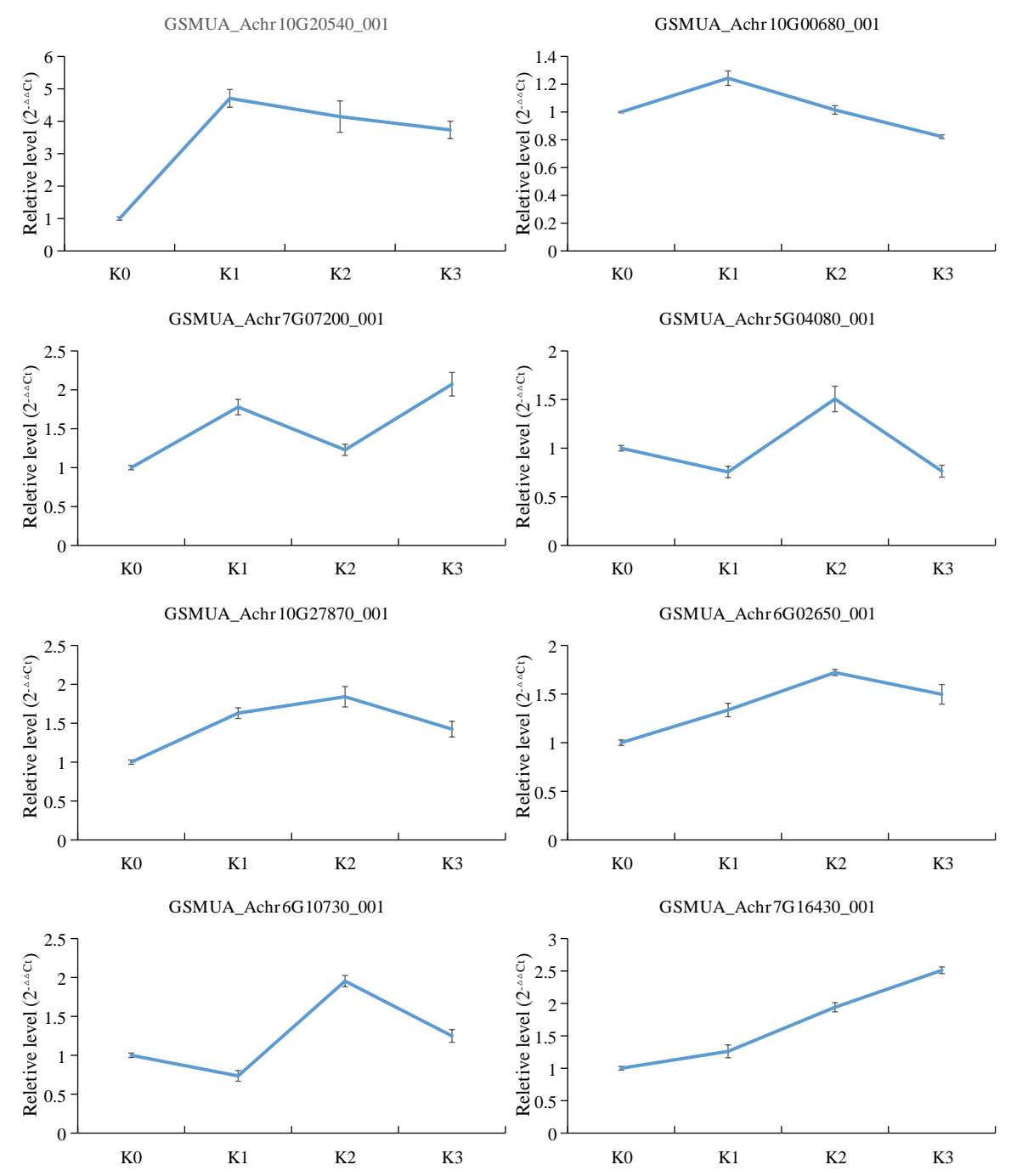

Figure 7. Relative gene expression of 8 randomly selected genes. The blue lines represent the relative intensity of real-time quantitative RT-PCR. The experiments were repeated three times. The error bars represent \pm SE. $n=3$.

\section{Discussion}

Plant roots can sense changes in the external environment and adjust the absorptive capacity by changing root morphology [30]. The length and surface area of a root system can be enhanced in potassium-rich soil, while the length and surface area of root system can be restricted in potassium-deficient soil [31-33]. Thus, it was not surprising to detect the inhibition of banana root hair growth in potassium deficiency (K0) and low potassium (K1) treatments, in the present study. As it was rarely reported the regulation of high potassium levels on plant root growth, it was meaningful to find out that the banana root length increased and root hairs were inhibited under the high potassium (K3) treatment. With the purpose to finding out the mechanism of different potassium levels in regulating the banana root growth, we performed the RNA-seq transcriptome analysis. The expression profile analysis of DEGs showed six significantly profiles, including profile $0,1,2,7,9$ and 13 (Figure 6). Coincidentally, the expression trend of 393 DEGs in profile 1 was contrary with the root growth phenotype change trend treated by different levels of potassium. These genes were up-regulated by potassium stresses compared with normal potassium level, and it is speculated that they were the main genes leading the change of root phenotype. GO enrichment analysis showed 
that one GO term (including 17 DEGs), which is related to oxidoreductase activity, was significantly enriched in profile 1 (Table 2). The 17 DEGs included nine Cytochrome P450 family members, four oxidoreductase family members, two 1-aminocyclopropane-1-carboxylate oxidase family members, one Omega-6 fatty acid desaturase, and one S-norcoclaurine synthase (Table S15). The oxidoreductase activity enrichment also had reported in other plants treated by low nutrient stresses, such as in low potassium treated pear fruit [34], in low nitrogen treated wheat [35], in low phosphorus treated sorghum [36]. The networks of the DEGs in profile 1 were conducted, and the results revealed that CYP51, a member of cytochrome P450 family was the hub gene with the highest node degree 8 (Figure 6B, Tables S5 and S6). In low potassium treated pear fruit, there multiple cytochrome P450 members were detected [34]. In low potassium treated tobacco, 3 cytochrome $\mathrm{P} 450$ members were also up-regulated [37]. The DEGs belong to cytochrome P450 family were also detected from potassium deficiency tomato [38], low-N polar [39], rice [40], sorghum [41] and wild barley [42]. Cytochrome P450 family genes were reported to participate in the biosynthesis of lignin precursors or hormone homeostasis [43], involved in the formation of cell wall and regulated the plant growth [44]. Therefore, the focus of CYP51 gene in DEGs interaction network of profile 1, indicated a significant correlation with root morphological changes under potassium stresses.

In profile 7, the DEGs were high regulated at low potassium levels $(\mathrm{K} 0, \mathrm{~K} 1)$ compared to $\mathrm{K} 2$ and K3 (Figure 6). GO analysis showed that the ion binding, transporter activity, Kinase, oxidoreductase activity, Transcription factors related DEGs were significantly enriched in profile 7 (Table 2). The DEGs interaction network indicated that SOS1 was the hub gene with 10 nodes (Figure 6C, Tables S7 and S8). SOS1 is a plasma membrane $\mathrm{Na}^{+} / \mathrm{H}^{+}$antiporter and belongs to the "salt overly sensitive" (SOS) signaling pathway [45]. It was reported to be an important gene locus for salt tolerance and potassium acquisition in plants [46-48]. Previous studies showed that SOS1 plays an essential function in regulating the spatial distribution and long-distance transportation of $\mathrm{Na}^{+}$and $\mathrm{K}^{+}$, the transport system of $\mathrm{K}^{+}$and $\mathrm{Na}^{+}$, keeping the $\mathrm{Na}^{+}$and $\mathrm{K}^{+}$homeostasis, and maintaining the normal growth of plants [49]. Here, the SOS1 was at a pivotal position in the interaction network of profile 7 DEGs, indicating that it played a key role in regulating banana root response to potassium stress. Early studies revealed that the CBL1/CBL9-CIPK23-AKT1 module is the primary $\mathrm{K}^{+}$uptake regulatory pathway to plants response in potassium starvation [50]. However, in our study, the AKT1, CBL1, and CBL9 were not present in the interacting networks of profile 7 . Then we dug into the transcriptome data and found that they were also not present in 4454 DEGs. The results suggested that the CBL1/CBL9-CIPK23-AKT1 pathway was not involved in banana root system in response to potassium stress. AtKC1 is a $\mathrm{K}^{+}$channel regulatory subunit, which together with $A t C I P K 23$, has been reported to coordinate the regulation of AtAKT1-mediated $\mathrm{K}^{+}$short stress response in Arabidopsis [51,52]. In addition, the CBL4/CIPK6 complex was revealed to modulating AKT2 activity in Arabidopsis [53]. CBL4 (SOS3) interacted with SOS2, and further activated SOS1 by phosphorylation [54-56]. TPK1, a voltage independent, $\mathrm{Ca}^{2+} / \mathrm{pH}$-activated two-pore $\mathrm{K}^{+}$channel, was proved playing key functions in keeping intracellular $\mathrm{K}^{+}$homeostasis $[57,58]$. KUP3 belongs to the largest potassium transporter HAK/KUP/KT family, which was strong inducted by potassium starvation [59]. In this study, it was predicted that $K C 1$ interacted with CIPK23, TPK1 and KUP3 respectively, and CIPK23 also interacted with SOS1 and CBL4(SOS3) respectively (Figure 6C). Given that the interaction between SOS1 and SOS3 [56], KC1 and CIPK23 [51,52], CBL4(SOS3) and CIPK6 [53] has been proved, thus the consistent expression and their interaction of SOS1, KC1, CIPK23, CBL4, CIPK6, KUP3, TPK1 in the network, provide new possible mechanisms for banana roots to response to potassium stress. In a word, the genes in profile 7 were mainly related to ion transport of potassium.

The 537 DEGs in Profile 0 were significantly down-regulated with the potassium concentration increase. In the profile 0 PPI network, five genes, including FKF1, HsP70-1, NRT1/PTR5, CRY1, and ZIP11, were strongly connected to other genes, indicated that they were hub genes in profile 0 (Figure 6A). The five hub genes were connected by several transcription factors including MYBs and bHLHs. There were also many $\mathrm{HsP}$ transcription factors in the network (Figure 6A, Tables S3 and S4). A 
recent study showed that cryptochrome 1 (CRY1, plant blue light photoreceptor) actively participates in the formation of secondary cell walls. When CRY1 gene was missing in plants, it will lead to the decrease of cellulose and lignin accumulation in plant stems [60]. Later, FLAVIN-BINDING KELCH REPEAT, F-BOX 1 (FKF1), another blue light receptor, was identified from cellulose synthase-deficient dwarf mutant, and revealed its role in negatively regulation of cellulose biosynthesis [61]. In this study, the hub location of $C R Y 1$ and FKF1 in the interaction network of profile 0 , indicated that the banana roots might change their cell wall component to response to different potassium stress. In this network, ZIP11, a zinc transporter gene, existed in the hub location. Members of the ZIP family were considered to be important transporters of $\mathrm{Zn}, \mathrm{Fe}, \mathrm{Mn}, \mathrm{Cu}$ and other bivalent metal ions [62-64]. Previous studies indicated that the relationship between Zinc and potassium in plants is mutual promotion. As the content of $\mathrm{Zn}$ in the body increases, the content of $\mathrm{K}$ also increases in cotton [65]. ZIP11 has the function of separating $\mathrm{Zn} / \mathrm{Cd}$ into vesicles and holding back its transfer from root to bud [66]. In addition, there were also some other ZIP or metal transport related genes such as IRT1, HMA2, ZIP5 in this interaction network. Therefore, the different potassium stress in banana roots might cause different zinc or other metal levels in roots through the ZIPs regulating network. A NRT1/PTR family gene, known for specific nitrate and auxin uptake, was found in the hub location of the interaction network of profile 0 . It is well known that the nitrogen and potassium fertilizers are interdependent. The expression of several NRT1/PTR genes regulated by external potassium has also been reported on tomato [67], and Arabidopsis [16]. In addition, it has been mentioned that NRT1.1 plays a key role in the $\mathrm{K}^{+}$translocation of Arabidopsis thaliana [68]. The present results were consistent with previous studies, indicating that the exogenous potassium stress can also affect the absorption and transport of nitrogen in banana root. Plant heat shock protein (Hsps) is a kind of protein that can be activated and produced in large quantities when plants encounter abiotic stress. Hsps has the function of molecular chaperone. It can maintain the stability of protein and cell membrane by assisting protein folding, assembly, translocation and degradation, and protect the normal growth of plants [69]. The HSP70 expression has been paid attention in plant response to abiotic stress, for instance drought [70,71] and salt [35,72]. However, its expression in plants response to potassium stress, was rarely mentioned. Nevertheless, its role in human potassium channels has been proven [72,73]. According to the above analysis, genes in profile 0 were mainly related to regulating cell wall formation, other nutrition transport and the Hsps expression.

In profile 9, the $596 \mathrm{DEGs}$ present no change from $\mathrm{K} 0$ to $\mathrm{K} 2$, but down-regulated from $\mathrm{K} 2$ to $\mathrm{K} 3$. In profile 9, THA, LKR/SDH, MCC, C4H, CHI, F3' H, PR1s, BSP, TLP, ICS, RO, chitinase, peroxidase were the hub genes with the node degree more than 8 (Figure 6D, Tables S9 and S10). THA, LKR/SDH, MCC, C4H, CHI, F3' H, ICS, chitinase and peroxidase belong to the metabolic pathways. Threonine aldolase $(T H A)$ is involved in the metabolic process of threonine. Threonine is lysed into glycine and acetic acid under the action of threonine aldolase. The results showed that glycine, under the action of glycine methyltransferase, synthesized betaine through three steps of methylation, thus improving the stress resistance of plants [74]. THA may be an important step in the regulation of amino acid metabolism in banana roots under adverse potassium conditions. LKR/SDH (Lysine ketoglutaric acid reductase/saccharopine dehydropine dehydrogenase) participating in the Lys degradation, is found to be a bifunctional enzyme [75]. The expression of $L K R / S D H$ was affected by lysine, osmotic stress, abscisic acid, sugar, jasmonate, nitrogen, salt and drought stresses [76-78]. This study indicated that, the expression of $L K R / S D H$ was depressed by high concentration of potassium. Leucine is a branched amino acid involved in the breakdown of large amounts of protein, which accumulates instantaneously in carbon-hungry cells. Methylcrotonoyl-CoA carboxylase (MCC), a mitochondria-localized carboxylase, is involved in the leucine catabolizing pathway [79-81]. It is expressed in a large number of sycamore cells during starvation [81,82]. Therefore, MCCase has been proposed as a new biochemical marker of carbohydrate starvation autophagy process [79]. Knockout of $M C C a$ or $M C C b$ results in impaired reproductive growth phenotypes in Arabidopsis thaliana [82]. It was also reported that MCC plays an important role in regulating triglyceride accumulation in Phaeodactylum tricornutum [83]. During 
cotyledon development, MCCase mRNA accumulation was positively correlated with the increase of organ age [80]. Biotinylation, a post-translational modification, is important for the activity of MCC, which has been demonstrated in tomato [84]. The expression profile of $M C C$ in banana roots treated by different potassium levels, which provided new evidence for its molecular regulatory function. Cinnamate 4-hydroxylase ( $\mathrm{C} 4 \mathrm{H}, \mathrm{EC}$ 1.14.13.11) is one of the key enzymes in the phenylpropanoid pathway, which is also the first Cyt P450-dependent monooxygenase of the pathway [85]. The expression of $\mathrm{C} 4 \mathrm{H}$ can be regulated by various environmental stresses. In Arabidopsis [86], Dryopteris fragrans [87], and Salvia miltiorrhiza [88], $\mathrm{C4H}$ was induced by light, UVB. In rice [89], orange [90], Carthamus tinctorius [91] and kenafcold [92], $\mathrm{C} 4 \mathrm{H}$ was induced by $\mathrm{NaCl}$, cold, $\mathrm{H}_{2} \mathrm{O}_{2}, \mathrm{ABA}$ and salicylic acid (SA). In Capsicum [93], C4H was induced by drought stress. Chalcone isomerase (CHI; EC 5.5.1.6) catalyze conversion of chalcone to flavonoids to produce most major flavonoid subgroups [94]. The correlation between $\mathrm{CHI}$ activity and plant response to environmental stress has been investigated. For example, the addition of fungal inducers led to rapid accumulation of $C H I$ mRNA in bean cell culture [95]; overexpressing GmCHI1A can decrease the harm by Phytophthora sojae in soybean [96]. Similarly, the transcription of $\mathrm{CHI}$ gene was induced by salt stress [97-99]. F3' $\mathrm{H}$ belongs to the cytochrome P450 subfamily and catalyzes the NADPH-dependent monooxygenase reactions [100]. It also participates in the flavonoid biosynthetic pathway. Our work showed that $\mathrm{C} 4 \mathrm{H}, \mathrm{CHI}$, and $\mathrm{F}^{\prime} \mathrm{H}$ in banana root were significantly down-regulated under high level potassium stress. In addition, they were also in the hub of the interaction network. It indicates that high potassium stress may inhibit the flavonoid biosynthesis pathway dominated by $\mathrm{C} 4 \mathrm{H}, \mathrm{CHI}$ and $F 3^{\prime} \mathrm{H}$ genes in banana roots. Peroxidase (POD, EC 1.11.1.7) is a recognized enzyme that affects plant growth through regulation of the lignin accumulation [101,102]. The increase of ion-binding POD activity inhibited root growth of rice [103]. By adding substances that inhibit pod activity, cell wall rigidity caused by pod can be removed and root elongation can be promoted [104]. Therefore, the down-regulation of peroxidase gene expression in profile 9 under high potassium treatment, might be the main reason which cause the banana root length increase. It is well known that $P R 1$, chitinases, thaumatin-like proteins, peroxidases have been classified as PR proteins, which are associated with plant defense [105]. Isochorismate synthase 1 (ICS1) is an essential enzyme in the synthesis of salicylic acid (SA). The SA can be synthesized by isochorismate synthase (ICS) pathway, and also can be synthesized by phenylalanine ammonia-lyase (PAL) pathway in plants [106,107]. In Arabidopsis, PAL pathway is mainly for the basic production of SA, while ICS pathway is for the production of pathogen-induced SA [108-110]. The accumulation of SA can induce the expression of the pathogenesis-related gene (PR1), which is considered to be an SA receptor in plants [111-114]. Our study showed that the chitinases, thaumatin-like proteins, peroxidases, ICS1, and 2 PR1 genes were down regulated under high level potassium stress. As they were located in the core location, therefore, it was speculated that high concentration of potassium inhibited their expression and would reduce the disease resistance of banana roots. In conclusion, the genes in profile 9 were suppressed by high potassium, and these genes mainly involved in the metabolic function and plant defense.

\section{Materials and Methods}

\subsection{Plant Materials and Different Potassium Treatments}

One-month-old young Brazilian bananas were washed and transplanted into plastic containers filled with vermiculite and grown in a greenhouse. The culture condition was $28 \pm 1{ }^{\circ} \mathrm{C}, 16 \mathrm{~h} / \mathrm{d}$ light, $60-70 \%$ relative humidity. The plants were wet thoroughly by special nutrient solution every 5 days. Basic nutrient solution was made up of $4 \mathrm{mmol} / \mathrm{L} \mathrm{Ca}\left(\mathrm{NO}_{3}\right)_{2} \cdot 4 \mathrm{H}_{2} \mathrm{O}, 3 \mathrm{mmol} / \mathrm{L} \mathrm{NH}_{4} \mathrm{NO}_{3}, 1 \mathrm{mmol} / \mathrm{L}$ $\mathrm{NH}_{4} \mathrm{H}_{2} \mathrm{PO}_{4}, 2 \mathrm{mmol} / \mathrm{L} \mathrm{MgSO} \cdot 7 \mathrm{H}_{2} \mathrm{O}$, iron salts and micronutrient were formulated with Hoagland nutrient solution. Four potassium levels from no potassium to high potassium were set to add $0(\mathrm{~K} 0)$, $0.03(\mathrm{~K} 1), 3(\mathrm{~K} 2), 200(\mathrm{~K} 3) \mathrm{mmol} / \mathrm{L} \mathrm{K}_{2} \mathrm{SO}_{4}$ respectively. After four weeks of potassium stress, banana 
roots were observed, photographed and sampled. The potassium stress treatment of banana root with different concentration was repeated three times.

\subsection{Extraction of Total RNA from Banana Root under Different Potassium Stresses}

Total RNA of banana root treated with different potassium was extracted according to the instructions of Trizol Kit (Promega, USA), after that the RNase-free DNase I (Takara Bio, Shiga, Japan) was added to eliminate residual DNA. The 2100 Bioanalyzer (Agilent Technologies, Santa Clara, CA, USA) was used to checked the RNA quality and concentration. Equal amounts of RNA from each sampled tissue were mixed for the subsequent steps of our experiments. Three biological replicates were performed and each biological replicate was constituted by a pool of three plants.

\subsection{RNA-Seq Library Preparation, Sequencing and Data Analysis}

The construction method of the library was the same as that reported by Balic et al. [115]. After being purified and enriched, the $200 \mathrm{bp} \pm 25 \mathrm{bp}$ cDNA fragments were used to construct cDNA library. The cDNA library sequencing was performed by Gene Denovo Biotechnology Co. (Guangzhou, China) using the Illumina HiSeq ${ }^{\mathrm{TM}}$ 2000. Then the obtained sequences were checked to delete the low-quality sequences. In addition, the retained high-quality sequences were assembled. Sequencing reads were mapped to banana genome sequences (https://banana-genome-hub.southgreen.fr/) by SOAPaligner/soap2. The uniquely mapped reads were used to evaluate the expression level. The formula of RPKM=106C/NL/103 was used to evaluate the expression level as described before [116]. The RPKM value is then used for pairwise comparisons between samples. The gene expression meeting the condition of $p$-value $<0.05, \log 2 \mathrm{FC} \geq 1$ were determined to be significantly different expression. The raw data was uploaded to NCBI, and the BioProject ID is PRJNA589855.

\subsection{Data Statistics, GO Enrichment, Expression Trend Analysis and Interactive Network Construction of DEGs}

The bar chart is drawn on an EXCEL spreadsheet. Analysis of Venn, upset Venn, GO enrichment and gene expression trend were drawn by appropriate software from OMICSHARE platform (https: //www.omicshare.com/), respectively. The protein interactive networks were constructed by the STRING online tool (https://string-db.org/).

\subsection{RNA-Seq Reliability Verification}

To assess the accuracy of sequencing data, we randomly selected 8 banana DEGs and the banana actin gene (an internal control), to do the following Quantitative Real-Time PCR analysis (qRT-PCR). Gene-specific primers (Table S16) were designed and analyzed on the online primer tool (https://www.ncbi.nlm.nih.gov/tools/primer-blast/). RT reagent Kit No. RR047Q (TaKaRa, Beijing, China) were used to reverse transcribe RNA into cDNA. The reaction solution of qRT-PCR was configured by the reagent No. RR820L (TaKaRa, Beijing, China). The reaction equipment is ABI 7900 HT Fast Real-Time PCR System (Applied Biosystems, Foster City, CA, USA). The relative gene expression value was analyzed using the $2^{-\Delta \Delta C t}$ formula, and three biological replicates were used in this research. The data was statistically analyzed and figured by Excel.

\section{Conclusions}

In this study, the morphological changes and DEGs of banana roots under different potassium stress were systematically understood. The results suggested that different potassium concentrations had various effects on the root phenotype of banana. 4454 DEGs were obtained in roots. Gene function classification enrichment was shown in the paper. six significant expression profiles were conducted. The core genes in each expression pattern were screened out. In conclusion, this study revealed the influence of potassium level on banana root system and the molecular regulation mechanism and provided a new idea for improving the use efficiency of banana potassium. 
Supplementary Materials: The following are available online at http://www.mdpi.com/2223-7747/9/1/11/s1, Figure S1: Interaction network of DEGs in profile 2, Figure S2: Interaction network of DEGs in profile 13. Table S1: Transcript abundance measurements at each potassium concentration treatment, Table S2: GO molecular function analysis of DEGs detected in banana roots in response to different concentration of potassium, Table S3: annotation of genes in profile 0, Table S4: The interaction data of DEGs in profile 0, Table S5: annotation of genes in profile 1, Table S6: The interaction data of DEGs in profile 1, Table S7: annotation of genes in profile 7, Table S8: The interaction data of DEGs in profile 7, Table S9: annotation of genes in profile 9; Table S10: The interaction data of DEGs in profile 9, Table S11: annotation of genes in profile 2, Table S12: The interaction data of DEGs in profile 2, Table S13: annotation of genes in profile 13, Table S14: The interaction data of DEGs in profile 13, Table S15: Annotation of DEGs of the significant GO term in profile 1, Table S16: Primer information for qRT-PCR.

Author Contributions: Conceptualization, Y.H. and R.L.; methodology, Y.H., F.L. and Y.X.; investigation, Y.H., F.L., Y.X. and L.W.; resources, B.W.; writing-original draft preparation, Y.H. and R.L.; writing-review and editing, J.G. and C.H.; visualization, R.L. and Y.H.; supervision, J.G. and C.H. All authors have read and agreed to the published version of the manuscript.

Funding: This research was funded by the Central Public-interest Scientific Institution Basal Research Fund for Innovative Research Team Program of CATAS (NO. 17CXTD-02, NO. 1630092020002), the Earmarked Fund for China Agriculture Research System (CARS-31-19, CARS-31-02).

Acknowledgments: We fully appreciate the editors and the reviewers for their constructive comments for this manuscript.

Conflicts of Interest: The authors declare no conflict of interest.

\section{References}

1. Rogiers, S.Y.; Coetzee, Z.A.; Walker, R.R.; Deloire, A.; Tyerman, S.D. Potassium in the grape (Vitis vinifera L.) berry: Transport and function. Front. Plant Sci. 2017, 8, 1629. [CrossRef] [PubMed]

2. Clarkson, D.T.; Hanson, J.B. The mineral nutrition of higher plants. Annu. Rev. Plant Physiol. 2003, 31, 239-298. [CrossRef]

3. Leigh, R.A.; Jones, R.G.W. A hypothesis relating critical potassium concentrations for growth to the distribution and functions of this ion in the plant cell. New Phytol. 1984, 97, 1-13. [CrossRef]

4. Ma, T.L.; Wu, W.H.; Wang, Y. Transcriptome analysis of rice root responses to potassium deficiency. BMC Plant Biol. 2012, 12, 161. [CrossRef] [PubMed]

5. Ahanger, M.A.; Agarwal, R.M.; Tomar, N.S.; Shrivastava, M. Potassium induces positive changes in nitrogen metabolism and antioxidant system of oat (Avena sativa L. cultivar Kent). J. Plant Interact. 2015, 10, 211-223. [CrossRef]

6. Ahanger, M.A.; Agarwal, R.M. Potassium up-regulates antioxidant metabolism and alleviates growth inhibition under water and osmotic stress in wheat (Triticum aestivum L.). Protoplasma 2017, 254, 1471-1486. [CrossRef] [PubMed]

7. Ahanger, M.A.; Tittal, M.; Mir, R.A.; Agarwal, R.M. Alleviation of water and osmotic stress-induced changes in nitrogen metabolizing enzymes in Triticum aestivum L. cultivars by potassium. Protoplasma 2017, 254, 1953-1963. [CrossRef]

8. Shabala, S. Salinity and programmed cell death: Unravelling mechanisms for ion specific signalling. J. Exp. Bot. 2009, 60, 709-712. [CrossRef]

9. Shabala, S. Signalling by potassium: Another second messenger to add to the list? J. Exp. Bot. 2017, 68, 4003-4007. [CrossRef]

10. Dordas, C. Role of nutrients in controlling plant diseases in sustainable agriculture. Agron. Sustain. Dev. 2008, 2, 33-46. [CrossRef]

11. Wang, M.; Zheng, Q.; Shen, Q.; Guo, S. The critical role of potassium in plant stress response. Int. J. Mol. Sci. 2013, 14, 7370-7390. [CrossRef] [PubMed]

12. Holzmueller, E.J.; Jose, S.; Jenkins, M.A. Influence of calcium, potassium, and magnesium on Cornus florida L. density and resistance to dogwood anthracnose. Plant Soil 2007, 290, 189-199. [CrossRef]

13. Gao, X.; Zhang, S.; Zhao, X.; Wu, Q. Potassium-induced plant resistance against soybean cyst nematode via root exudation of phenolic acids and plant pathogen-related genes. PLOS ONE 2018, 13, e0200903. [CrossRef] [PubMed]

14. Kanai, S.; Moghaieb, R.E.; El-Shemy, H.A.; Panigrahi, R.; Mohapatra, P.K.; Ito, J.; Nguyen, N.T.; Saneoka, H.; Fujita, K. Potassium deficiency affects water status and photosynthetic rate of the vegetative sink in green 
house tomato prior to its effects on source activity. Plant Sci. Int. J. Exp. Plant Biol. 2011, 180, 368. [CrossRef] [PubMed]

15. Hetherington, M. The Response of Arabidopsis to Low Potassium Availability. Ph.D. Thesis, Durham University, Durham, UK, 2018.

16. Armengaud, P. The potassium-dependent transcriptome of Arabidopsis reveals a prominent role of jasmonic acid in nutrient signaling. Plant Physiol. 2004, 136, 2556-2576. [CrossRef] [PubMed]

17. Gruber, B.D.; Giehl, R.F.H.; Swetlana, F.; Nicolaus, W. Plasticity of the Arabidopsis root system under nutrient deficiencies. Plant Physiol. 2013, 163, 161-179. [CrossRef] [PubMed]

18. Zhao, X.-H.; Yu, H.-Q.; Wen, J.; Wang, X.-G.; Du, Q.; Wang, J.; Wang, Q. Response of root morphology, physiology and endogenous hormones in maize (Zea mays L.) to potassium deficiency. J. Integr. Agric. 2016, 15, 785-794. [CrossRef]

19. Dun, X.; Shi, J.; Liu, H.; Wang, J.; Wang, X.; Wang, H. Genetic dissection of root morphological traits as related to potassium use efficiency in rapeseed under two contrasting potassium levels by hydroponics. Sci. China Life Sci. 2019, 62, 746-757. [CrossRef]

20. Song, W.; Liu, S.; Meng, L.; Xue, R.; Wang, C.; Liu, G.; Dong, C.; Wang, S.; Dong, J.; Zhang, Y. Potassium deficiency inhibits lateral root development in tobacco seedlings by changing auxin distribution. Plant Soil 2015, 396, 163-173. [CrossRef]

21. Zhang, J.; Wang, Y.; Wang, P.; Zhang, Q.A.; Yan, C.; Yu, F.; Yi, J.; Fang, L. Effect of different levels of nitrogen, phosphorus, and potassium on root activity and chlorophyll content in leaves of Brassica oleracea seedlings grown in vegetable nursery substrate. Hortic. Environ. Biotechnol. 2017, 58, 5-11. [CrossRef]

22. Shahzad, Z.; Amtmann, A. Food for thought: How nutrients regulate root system architecture. Curr. Opin. Plant Biol. 2017, 39, 80-87. [CrossRef] [PubMed]

23. Wang, C.; Chen, H.; Hao, Q.; Sha, A.; Shan, Z.; Chen, L.; Zhou, R.; Zhi, H.; Zhou, X. Transcript profile of the response of two soybean genotypes to potassium deficiency. PLOS ONE 2012, 7, e39856. [CrossRef] [PubMed]

24. Zeng, J.; He, X.; Wu, D.; Zhu, B.; Cai, S.; Nadira, U.A.; Jabeen, Z.; Zhang, G. Comparative transcriptome profiling of two Tibetan wild barley genotypes in responses to low potassium. PLOS ONE 2014, 9, e100567. [CrossRef] [PubMed]

25. Zeng, Q.; Ling, Q.; Fan, L.; Li, Y.; Hu, F.; Chen, J.; Huang, Z.; Deng, H.; Li, Q.; Qi, Y. Transcriptome profiling of sugarcane roots in response to low potassium stress. PLOS ONE 2015, 10, e0126306. [CrossRef] [PubMed]

26. Zhang, X.; Jiang, H.; Wang, H.; Cui, J.; Wang, J.; Hu, J.; Guo, L.; Qian, Q.; Xue, D. Transcriptome analysis of rice seedling roots in response to potassium deficiency. Sci. Rep. 2017, 7, 5523. [CrossRef] [PubMed]

27. Sung, J.; Lee, S.; Lee, Y.; Ha, S.; Song, B.; Kim, T.; Waters, B.M.; Krishnan, H.B. Metabolomic profiling from leaves and roots of tomato (Solanum lycopersicum L.) plants grown under nitrogen, phosphorus or potassium-deficient condition. Plant Sci. 2015, 241, 55-64. [CrossRef]

28. Li, G.; Wu, Y.; Liu, G.; Xiao, X.; Wang, P.; Gao, T.; Xu, M.; Han, Q.; Wang, Y.; Guo, T.; et al. Large-scale proteomics combined with transgenic experiments demonstrates an important role of jasmonic acid in potassium deficiency response in wheat and rice. Mol. Cell. Proteom. 2017, 16, 1889-1905. [CrossRef]

29. Sansoulet, J.; Cabidoche, Y.M.; Cattan, P. Adsorption and transport of nitrate and potassium in an Andosol under banana (Guadeloupe, French West Indies). Eur. J. Soil Sci. 2007, 58, 478-489. [CrossRef]

30. Schachtman, D.P.; Shin, R. Nutrient sensing and signaling: NPKS. Annu. Rev. Plant Biol. 2007, 58, 47-69. [CrossRef]

31. Fernández, F.G.; Brouder, S.M.; Volenec, J.J.; Beyrouty, C.A.; Hoyum, R. Soybean shoot and root response to localized water and potassium in a split-pot study. Plant Soil 2011, 344, 197-212. [CrossRef]

32. Kellermeier, F.; Chardon, F.; Amtmann, A. Natural variation of Arabidopsis root architecture reveals complementing adaptive strategies to potassium starvation. Plant Physiol. 2013, 161, 1421-1432. [CrossRef] [PubMed]

33. Ruan, L.; Xin, X.; Zhang, J.; Zhao, B.; Cheng, H.; Zhang, C.; Ma, D.; Chen, L. Potential root foraging strategy of wheat (Triticum aestivum L.) for potassium heterogeneity. Front. Plant Sci. 2018, 9, 1755. [CrossRef] [PubMed]

34. Shen, C.; Wang, J.; Shi, X.; Kang, Y.; Xie, C.; Peng, L.; Dong, C.; Shen, Q.; Xu, Y. Transcriptome analysis of differentially expressed genes induced by low and high potassium levels provides insight into fruit sugar metabolism of pear. Front. Plant Sci. 2017, 8, 938. [CrossRef] [PubMed] 
35. Wang, M.; Wang, Y.; Zhang, Y.; Li, C.; Gong, S.; Yan, S.; Li, G.; Hu, G.; Ren, H.; Yang, J.; et al. Comparative transcriptome analysis of salt-sensitive and salt-tolerant maize reveals potential mechanisms to enhance salt resistance. Genes Genom. 2019, 41, 781-801. [CrossRef] [PubMed]

36. Zhang, J.; Jiang, F.; Shen, Y.; Zhan, Q.; Chi, Y. Transcriptome analysis reveals candidate genes related to phosphorus starvation tolerance in sorghum. BMC Plant Biol. 2019, 19, 306. [CrossRef] [PubMed]

37. Li, L.; Li, J.; Chen, Y.; Lu, Y.; Lu, L. De novo transcriptome analysis of tobacco seedlings and identification of the early response gene network under low-potassium stress. Genet. Mol. Res. 2016, 15, gmr.15038599. [CrossRef] [PubMed]

38. Zhao, X.; Liu, Y.; Liu, X.; Jiang, J. Comparative transcriptome profiling of two tomato genotypes in response to potassium-deficiency stress. Int. J. Mol. Sci. 2018, 19, 2402. [CrossRef]

39. Calabrese, S.; Kohler, A.; Niehl, A.; Veneault-Fourrey, C.; Courty, P.E. Transcriptome analysis of the populus trichocarpa-rhizophagus irregularis mycorrhizal symbiosis: Regulation of plant and fungal transportomes under nitrogen starvation. Plant Cell Physiol. 2017, 58, 1003-1017. [CrossRef]

40. Cai, H.; Lu, Y.; Xie, W.; Zhu, T.; Lian, X. Transcriptome response to nitrogen starvation in rice. J. Biosci. 2012, 37, 731-747. [CrossRef]

41. Gelli, M.; Duo, Y.; Konda, A.; Zhang, C.; Holding, D.; Dweikat, I. Identification of differentially expressed genes between sorghum genotypes with contrasting nitrogen stress tolerance by genome-wide transcriptional profiling. BMC Genom. 2014, 15, 179. [CrossRef]

42. Quan, X.; Zeng, J.; Ye, L.; Chen, G.; Han, Z.; Shah, J.M.; Zhang, G. Transcriptome profiling analysis for two tibetan wild barley genotypes in responses to low nitrogen. BMC Plant Biol. 2016, 16, 30. [CrossRef] [PubMed]

43. Nelson, D.; Werck-Reichhart, D. A P450-centric view of plant evolution. Plant J. 2011, 66, 194-211. [CrossRef] [PubMed]

44. Tamiru, M.; Undan, J.R.; Takagi, H.; Abe, A.; Yoshida, K.; Undan, J.Q.; Natsume, S.; Uemura, A.; Saitoh, H.; Matsumura, H.; et al. A cytochrome P450, OsDSS1, is involved in growth and drought stress responses in rice (Oryza sativa L.). Plant Mol. Biol. 2015, 88, 85-99. [CrossRef] [PubMed]

45. Shi, H.; Quintero, F.J.; Pardo, J.M.; Zhu, J.K. The putative plasma membrane $\mathrm{Na}^{+} / \mathrm{H}^{+}$antiporter SOS1 controls long-distance $\mathrm{Na}^{+}$transport in plants. Plant Cell 2002, 14, 465-477. [CrossRef] [PubMed]

46. Wu, S.J.; Ding, L.; Zhu, J.K. SOS1, a genetic locus essential for salt tolerance and potassium acquisition. Plant Cell 1996, 8, 617-627. [CrossRef] [PubMed]

47. Zhu, J.K.; Xiong, L.L. Genetic analysis of salt tolerance in Arabidopsis: Evidence for a critical role of potassium nutrition. Plant Cell 1998, 10, 1181-1191. [CrossRef] [PubMed]

48. Shabala, L.; Cuin, T.A.; Shabala, N.S. Salinity-induced ion flux patterns from the excised roots of Arabidopsis sos mutants. Planta 2005, 222, 1041-1050. [CrossRef] [PubMed]

49. Ma, Q.; Li, Y.X.; Yuan, H.J.; Hu, J.; Wei, L.; Bao, A.K.; Zhang, J.L.; Wang, S.M. ZxSOS1 is essential for long-distance transport and spatial distribution of $\mathrm{Na}^{+}$, and $\mathrm{K}^{+}$, in the xerophyte Zygophyllum xanthoxylum. Plant Soil 2014, 374, 661-676. [CrossRef]

50. Wang, Y.; Wu, W.H. Regulation of potassium transport and signaling in plants. Curr. Opin. Plant Biol. 2017, 39, 123-128. [CrossRef]

51. Jeanguenin, L.; Alcon, C.; Duby, G.; Boeglin, M.; Cherel, I.; Gaillard, I.; Zimmermann, S.; Sentenac, H.; Véry, A.-A. AtKC1 is a general modulator of Arabidopsis inward Shaker channel activity. Plant J. Cell Mol. Biol. 2011, 67, 570-582. [CrossRef]

52. Wang, X.P.; Chen, L.M.; Liu, W.X.; Shen, L.K.; Wang, F.L.; Zhou, Y.; Zhang, Z.; Wu, W.H.; Wang, Y. AtKC1 and CIPK23 synergistically modulate AKT1-mediated low-potassium stress responses in Arabidopsis. Plant Physiol. 2016, 170, 2264-2277. [CrossRef] [PubMed]

53. Held, K.; Pascaud, F.; Eckert, C.; Gajdanowicz, P.; Hashimoto, K.; Corratgé-Faillie, C.; Offenborn, J.N.; Lacombe, B.; Dreyer, I.; Thibaud, J.-B.; et al. Calcium-dependent modulation and plasma membrane targeting of the AKT2 potassium channel by the CBL4/CIPK6 calcium sensor/protein kinase complex. Cell Res. 2011, 21, 1116-1130. [CrossRef] [PubMed]

54. Halfter, U.; Ishitani, M.; Zhu, J.K. The Arabidopsis SOS2 protein kinase physically interacts with and is activated by the calcium-binding protein SOS3. Proc. Natl. Acad. Sci. USA 2000, 97, 3735-3740. [CrossRef] [PubMed] 
55. Shi, H.; Ishitani, M.; Kim, C.; Zhu, J.K. The Arabidopsis thaliana salt tolerance gene SOS1 encodes a putative $\mathrm{Na}^{+} / \mathrm{H}^{+}$antiporter. Proc. Natl. Acad. Sci. USA 2000, 97, 6896-6901. [CrossRef] [PubMed]

56. Yu, L.; Nie, J.; Cao, C.; Jin, Y.; Yan, M.; Wang, F.; Liu, J.; Xiao, Y.; Liang, Y.; Zhang, W. Phosphatidic acid mediates salt stress response by regulation of MPK6 in Arabidopsis thaliana. New Phytol. 2010, 188, 762-773. [CrossRef] [PubMed]

57. Latz, A.; Becker, D.; Hekman, M.; Müller, T.; Beyhl, D.; Marten, I.; Eing, C.; Fischer, A.; Dunkel, M.; Bertl, A.; et al. TPK1, a Ca ${ }^{2+}$-regulated Arabidopsis vacuole two-pore $\mathrm{K}^{+}$channel is activated by $14-3-3$ proteins. Plant J. 2007, 52, 449-459. [CrossRef]

58. Isner, J.C.; Begum, A.; Nuehse, T.; Hetherington, A.M.; Maathuis, F.J.M. KIN7 kinase regulates the vacuolar TPK1 $\mathrm{K}^{+}$, channel during stomatal closure. Curr. Biol. 2018, 28, 466-472. [CrossRef]

59. Kim, E.J.; Kwak, J.M.; Schroeder, U.J.I. AtKUP1: An Arabidopsis gene encoding high-affinity potassium transport activity. Plant Cell 1998, 10, 51-62. [CrossRef]

60. Zhang, Q.; Xie, Z.; Zhang, R.; Xu, P.; Liu, H.; Yang, H.-Q.; Doblin, M.S.; Bacic, A.; Li, L. Blue light regulates secondary cell wall thickening via MYC2/MYC4 activation of the NST1-directed transcriptional network in Arabidopsis. Plant Cell 2018, 30, 2512-2528. [CrossRef]

61. Yuan, N.; Balasubramanian, V.K.; Chopra, R.; Mendu, V. The photoperiodic flowering time regulator FKF1 negatively regulates cellulose biosynthesis. Plant Physiol. 2019, 180, 2240-2253. [CrossRef]

62. Grotz, N.; Guerinot, M.L. Molecular aspects of $\mathrm{Cu}, \mathrm{Fe}$ and $\mathrm{Zn}$ homeostasis in plants. Biochim. Biophys. Acta 2006, 1763, 595-608. [CrossRef] [PubMed]

63. Vigani, G.; Zocchi, G.; Bashir, K.; Philippar, K.; Briat, J.F. Cellular iron homeostasis and metabolism in plant. Front. Plant Sci. 2013, 4, 490. [CrossRef] [PubMed]

64. Boutigny, S.; Sautron, E.; Finazzi, G.; Rivasseau, C.; Frelet-Barrand, A.; Pilon, M.; Rolland, N.; Seigneurin-Berny, D. HMA1 and PAA1, two chloroplast-envelope play distinct roles in chloroplast copper homeostasis. J. Exp. Bot. 2014, 65, 1529-1540. [CrossRef] [PubMed]

65. Sathiyamurthi, S.; Dhanasekaran, K. Effects of different levels and sources of zinc on dry matter production and nutrient uptake by cotton (Gossypium hirsutum L.) in salt affected soil. Asian J. Soil Sci. 2015, 9, 208-212. [CrossRef]

66. Xu, J.; Sun, J.; Du, L.; Liu, X. Comparative transcriptome analysis of cadmium responses in Solanum nigrum and Solanum toroum. New Phytol. 2012, 196, 110-124. [CrossRef] [PubMed]

67. Wang, Y.H.; Garvin, D.F.; Kochian, L.V. Rapid induction of regulatory and transporter genes in response to phosphorus, potassium, and iron deficiencies in tomato roots. Evidence for cross talk and root/rhizosphere-mediated signals. Plant Physiol. 2002, 130, 1361-1370. [CrossRef]

68. Drechsler, N.; Zheng, Y.; Bohner, A.; Nobmann, B.; von Wirén, N.; Kunze, R.; Rausch, C. Nitrate-dependent control of shoot $\mathrm{K}$ homeostasis by the nitrate transporter1/peptide transporter family member NPF7.3/NRT1.5 and the Stelar $\mathrm{K}^{+}$Outward Rectifier SKOR in Arabidopsis. Plant Physiol. 2015, 169, 2832-2847.

69. Wang, W.; Vinocur, B.; Shoseyov, O.; Altman, A. Role of plant heat-shock proteins and molecular chaperones in the abiotic stress response. Trends Plant Sci. 2004, 9, 244-252. [CrossRef]

70. Banavath, J.N.; Chakradhar, T.; Pandit, V.; Konduru, S.; Guduru, K.K.; Akila, C.S.; Podha, S.; Puli, C.O.R. Stress inducible overexpression of AtHDG11 leads to improved drought and salt stress tolerance in peanut (Arachis hypogaea L.). Front. Chem. 2018, 6, 3-4. [CrossRef]

71. Zhang, X.; Wang, X.; Zhuang, L.; Gao, Y.; Huang, B. Abscisic acid mediation of drought priming-enhanced heat tolerance in tall fescue (Festuca arundinacea) and Arabidopsis. Physiol. Plant. 2019, 167, 488-501. [CrossRef]

72. Qu, J.; Tao, X.-Y.; Teng, P.; Zhang, Y.; Guo, C.-L.; Hu, L.; Qian, Y.-N.; Jiang, C.-Y.; Liu, W.-T. Blocking ATP-sensitive potassium channel alleviates morphine tolerance by inhibiting HSP70-TLR4-NLRP3-mediated neuroinflammation. J. Neuroinflamm. 2017, 14, 228. [CrossRef] [PubMed]

73. Ficker, E.; Dennis, A.T.; Wang, L.; Brown, A.M. Role of the cytosolic chaperones Hsp70 and Hsp90 in maturation of the cardiac potassium channel HERG. Circ. Res. 2003, 92, 87-100. [CrossRef] [PubMed]

74. Waditee, R.; Bhuiyan, N.H.; Rai, V.; Aoki, K.; Tanaka, Y.; Hibino, T.; Suzuki, S.; Takano, J.; Jagendorf, A.T.; Takabe, T; et al. Genes for direct methylation of glycine provide high levels of glycinebetaine and abiotic-stress tolerance in Synechococcus and Arabidopsis. Proc. Natl. Acad. Sci. USA 2005, 102, 1318-1323. [CrossRef] [PubMed] 
75. Zhu, X.; Tang, G.; Granier, F.; Bouchez, D.; Galili, G. A T-DNA insertion knockout of the bifunctional lysine-ketoglutarate reductase/saccharopine dehydrogenase gene elevates lysine levels in Arabidopsis seeds. Plant Physiol. 2001, 126, 1539-1545. [CrossRef] [PubMed]

76. Moulin, M.; Deleu, C.; Larher, F. L-lysine catabolism is osmo-regulated at the level of lysine-ketoglutarate reductase and saccharopine dehydrogenase in rapeseed leaf discs. Plant Physiol. Biochem. 2000, 38, 577-585. [CrossRef]

77. Stepansky, A.; Galili, G. Synthesis of the Arabidopsis bifunctional lysine-ketoglutarate reductase/saccharopine dehydrogenase enzyme of lysine catabolism is concertedly regulated by metabolic and stress-associated signals. Plant Physiol. 2003, 133, 1407. [CrossRef] [PubMed]

78. Yao, Y.; Tang, G.; Galili, G.; Stepansky, A. Regulation of lysine catabolism in Arabidopsis through concertedly regulated synthesis of the two distinct gene products of the composite AtLKR/SDH locus. J. Exp. Bot. 2005, 56,525 .

79. Aubert, S.; Alban, C.; Bligny, R.; Douce, R. Induction of $\beta$-methylcrotonyl-coenzyme A carboxylase in higher plant cells during carbohydrate starvation: Evidence for a role of MCCase in leucine catabolism. FEBS Lett. 1996, 383, 175-180. [CrossRef]

80. Anderson, M.D.; Che, P.; Song, J.; Nikolau, B.J.; Wurtele, E.S. 3-methylcrotonyl-coenzyme a carboxylase is a component of the mitochondrial leucine catabolic pathway in plants1. Plant Physiol. 1998, 118, 1127-1138. [CrossRef]

81. Binder, S. Branched-chain amino acid metabolism in Arabidopsis thaliana. Arabidopsis Book 2010, 8, e0137. [CrossRef]

82. Ding, G.; Che, P.; Ilarslan, H.; Wurtele, E.S.; Nikolau, B.J. Genetic dissection of methylcrotonyl CoA carboxylase indicates a complex role for mitochondrial leucine catabolism during seed development and germination. Plant J. 2012, 70, 562-577. [CrossRef] [PubMed]

83. Ge, F.; Hu, H. Methylcrotonyl-CoA carboxylase regulates triacylglycerol accumulation in the model diatom Phaeodactylum tricornutum. Plant Cell 2014, 26, 1681-1697. [CrossRef]

84. Wang, X.; Wurtele, E.S.; Nikolau, B.J. Regulation of $\beta$-methylcrotonyl-coenzyme A carboxylase activity by biotinylation of the apoenzyme. Plant Physiol. 1995, 108, 1133-1139. [CrossRef] [PubMed]

85. Bell-Lelong, D.A.; Cusumano, J.C.; Meyer, K.; Chapple, C. Cinnamate-4-hydroxylase expression in Arabidopsis (Regulation in response to development and the environment). Plant Physiol. 1997, 113, 729-738. [CrossRef] [PubMed]

86. Jin, H.; Cominelli, E.; Bailey, P.; Parr, A.; Mehrtens, F.; Jones, J.; Tonelli, C.; Weisshaar, B.; Martin, C. Transcriptional repression by AtMYB4 controls production of UV-protecting sunscreens in Arabidopsis. EMBO J. 2000, 19, 6150-6161. [CrossRef] [PubMed]

87. Li, Y.; Sun, L.; Wang, H.; Gao, R.; Zhang, J.; Hu, B.; Chang, Y. Cloning and expression analysis of phenylalanine ammonia-lyase (PAL) gene family and cinnamate 4-hydroxylase $(\mathrm{C} 4 \mathrm{H})$ from Dryopteris fragrans. Biologia 2015, 70, 606-614. [CrossRef]

88. Huang, B.; Duan, Y.; Yi, B.; Sun, L.; Lu, B.; Yu, X.; Sun, H.; Zhang, H.; Chen, W. Characterization and expression profiling of cinnamate 4-hydroxylase gene from Salvia miltiorrhiza in rosmarinic acid biosynthesis pathway. Russ. J. Plant Physiol. 2008, 55, 390-399. [CrossRef]

89. Kim, J.H.; Yun, P.Y.; Lee, Y.K.; Lim, Y.P.; Lee, M.C. cDNA cloning and sequence analysis of the rice cinnamate-4-hydroxylase gene, a cytochrome P450-dependent monooxygenase involved in the general phenylpropanoid pathway. J. Plant Biol. 2005, 48, 311-318.

90. Betz, C.; Mccollum, T.G.; Mayer, R.T. Differential expression of two cinnamate 4-hydroxylase genes in 'Valencia' orange (Citrus sinensis Osbeck). Plant Mol. Biol. 2001, 46, 741-748. [CrossRef]

91. Sadeghi, M.; Dehghan, S.; Fischer, R.; Wenzel, U.; Vilcinskas, A.; Kavousi, H.R.; Rahnamaeian, M. Isolation and characterization of isochorismate synthase and cinnamate 4-hydroxylase during salinity stress, wounding, and salicylic acid treatment in Carthamus tinctorius. Plant Signal. Behav. 2013, 8, 2420-2423. [CrossRef]

92. Jonggeun, K.; Bosung, C.; Natarajan, S.; Hanhong, B. Expression analysis of kenaf cinnamate 4-hydroxylase $(\mathrm{C} 4 \mathrm{H})$ ortholog during developmental and stress responses. Plant Omics 2013, 6, 65-72.

93. Phimchan, P.; Chanthai, S.; Bosland, P.W.; Techawongstien, S. Enzymatic changes in phenylalanine ammonia-lyase, cinnamic-4-hydroxylase, capsaicin synthase, and peroxidase activities in Capsicum under drought stress. J. Agric. Food Chem. 2014, 62, 7057. [CrossRef] [PubMed] 
94. Shimada, N.; Aoki, T.; Sato, S.; Nakamura, Y.; Tabata, S.; Ayabe, S.-I. A cluster of genes encodes the two types of chalcone isomerase involved in the biosynthesis of general flavonoids and legume-specific 5-deoxy(iso)flavonoids in Lotus japonicus. Plant Physiol. 2003, 131, 941-951. [CrossRef] [PubMed]

95. Mehdy, M.C.; Lamb, C.J. Chalcone isomerase cDNA cloning and mRNA induction by fungal elicitor, wounding and infection. EMBO J. 1987, 6, 1527-1533. [CrossRef]

96. Zhou, Y.; Huang, J.; Zhang, X.; Zhu, L.; Wang, X.; Guo, N.; Xing, H. Overexpression of chalcone isomerase (CHI) increases resistance against Phytophthora sojae in soybean. J. Plant Biol. 2018, 61, 309-319. [CrossRef]

97. Walia, H.; Wilson, C.; Zeng, L.; Ismail, A.M.; Condamine, P.; Close, T.J. Genome-wide transcriptional analysis of salinity stressed japonica and indica rice genotypes during panicle initiation stage. Plant Mol. Biol. 2007, 63, 609-623. [CrossRef]

98. Zamora, P.; Pardo, A.; Fierro, A.; Prieto, H.; Zuniga, G.E. Molecular characterization of the chalcone isomerase gene family in Deschampsia antarctica. Polar Biol. 2013, 36, 1269-1280. [CrossRef]

99. Shoeva, O.Y.; Khlestkina, E.K.; Bergès, H.; Salina, E.A. The homoeologous genes encoding chalcone-flavanone isomerase in Triticum aestivum L.: Structural characterization and expression in different parts of wheat plant. Gene 2014, 538, 334-341. [CrossRef]

100. Seitz, C.; Ameres, S.; Forkmann, G. Identification of the molecular basis for the functional difference between flavonoid 3'-hydroxylase and flavonoid 3',5'-hydroxylase. FEBS Lett. 2007, 581, 3429-3434. [CrossRef]

101. Siegel, S.M. Studies on the biosynthesis of lignins. Physiol. Plantarum 1954, 7, 41-50. [CrossRef]

102. Cosgrove, D.J. Assembly and enlargement of the primary cell wall in plants. Annu. Rev. Cell Dev. Biol. 1997, 13, 171-201. [CrossRef]

103. Lin, C.C.; Kao, C.H. Cell wall peroxidase activity, hydrogen peroxide level and NaCl-inhibited root growth of rice seedlings. Plant Soil 2001, 230, 135-143. [CrossRef]

104. Balzergue, C.; Dartevelle, T.; Godon, C.; Laugier, E.; Meisrimler, C.; Teulon, J.-M.; Creff, A.; Bissler, M.; Brouchoud, C.; Hagège, A.; et al. Low phosphate activates STOP1-ALMT1 to rapidly inhibit root cell elongation. Nat. Commun. 2017, 8, 15300. [CrossRef]

105. Loon, L.C.V.; Strien, E.A.V. The families of pathogenesis-related proteins, their activities, and comparative analysis of PR-1 type proteins. Physiol. Mol. Plant Pathol. 1999, 55, 85-97. [CrossRef]

106. Dempsey, D.A.; Vlot, A.C.; Wildermuth, M.C.; Klessig, D.F. Salicylic acid biosynthesis and metabolism. Arabidopsis Book 2011, 9, e0156. [CrossRef] [PubMed]

107. Seyfferth, C.; Tsuda, K. Salicylic acid signal transduction: The initiation of biosynthesis, perception and transcriptional reprogramming. Front. Plant Sci. 2014, 5, 697. [CrossRef]

108. Huang, J.; Gu, M.; Lai, Z.; Fan, B.; Shi, K.; Zhou, Y.-H.; Yu, J.-Q.; Chen, Z. Functional analysis of the Arabidopsis $P A L$ gene family in plant growth, development and response to environmental stress. Plant Physiol. 2010, 153, 1526-1538. [CrossRef]

109. Wildermuth, M.C.; Dewdney, J.; Wu, G.; Ausubel, F.M. Isochorismate synthase is required to synthesize salicylic acid for plant defence. Nature 2001, 414, 562-565. [CrossRef]

110. Garcion, C.; Lohmann, A.; Lamodiere, E.; Catinot, J.; Buchala, A.; Doermann, P.; Métraux, J.P. Characterization and biological function of the ISOCHORISMATE SYNTHASE2 gene of Arabidopsis. Plant Physiol. 2008, 147, 1279-1287. [CrossRef]

111. Kovacs, I.; Durner, J.; Lindermayr, C. Crosstalk between nitric oxide and glutathione is required for nonexpressor of pathogenesis-related genes 1 (NPR1)-dependent defense signaling in Arabidopsis thaliana. New Phytol. 2015, 208, 860-872. [CrossRef]

112. Wang, X.; Yang, B.; Li, K.; Kang, Z.; Cantu, D.; Dubcovsky, J. A conserved Puccinia striiformis protein interacts with wheat NPR1 and reduces induction of pathogenesis-related genes in response to pathogens. Mol. Plant Microbe Int. 2016, 29, 977-989. [CrossRef] [PubMed]

113. Zhang, X.; Chen, S.; Mou, Z. Nuclear localization of NPR1 is required for regulation of salicylate tolerance, isochorismate synthase 1 expression and salicylate accumulation in Arabidopsis. J. Plant Physiol. 2010, 167, 144-148. [CrossRef] [PubMed]

114. Ding, Y.; Sun, T.; Ao, K.; Peng, Y.; Zhang, Y.; Li, X.; Zhang, Y. Opposite roles of salicylic acid receptors NPR1 and NPR3/ NPR4 in transcriptional regulation of plant immunity. Cell 2018, 173, 1454-1467. [CrossRef] [PubMed] 
115. Balić, I.; Vizoso, P.; Nilo-Poyanco, R.; Sanhueza, D.; Olmedo, P.; Sepúlveda, P.; Arriagada, C.; Defilippi, B.G.; Meneses, C.; Campos-Vargas, R. Transcriptome analysis during ripening of table grape berry cv. Thompson Seedless. PLOS ONE 2018, 13, e0190087. [CrossRef] [PubMed]

116. Liu, X.; Yang, H.; Zheng, J.; Ye, Y.; Pan, L. Identification of strong promoters based on the transcriptome of Bacillus licheniformis. Biotechnol. Lett. 2017, 39, 873-881. [CrossRef] [PubMed]

(C) 2019 by the authors. Licensee MDPI, Basel, Switzerland. This article is an open access article distributed under the terms and conditions of the Creative Commons Attribution (CC BY) license (http://creativecommons.org/licenses/by/4.0/). 